\title{
Human health risk exposure and ecological risk assessment of potentially toxic element pollution in agricultural soils in the district of Frydek Mistek, Czech Republic: a sample location approach
}

Prince Chapman Agyeman * (D), Kingsley John, Ndiye Michael Kebonye, Luboš Borůvka, Radim Vašát, Ondřej Drábek and Karel Němeček

\begin{abstract}
Background: Human activities considerably contribute to polluting potentially toxic element (PTEs) levels in soils, especially agricultural soils. The consistent introduction of PTEs in the environment and the soil pose health-related risks to humans, flora and fauna. One hundred and fifteen samples were collected in the district of Frydek Mistek (Czech Republic) in a regular grid form. The soil samples were air-dried, and the concentrations of PTEs (i.e. lead, arsenic, chromium, nickel, manganese, cadmium, copper, and zinc) were determined by ICP-OES (inductively coupled plasma optical emission spectrometry). The purpose of this study is to create digitized soil maps that expose the human-related health risks posed by PTEs, estimate pollution indices, ascertain the spatially distributed patterns of PTEs, source apportionment and quantify carcinogenic and non-carcinogenic health risks using the sample location approach.

Results: The results revealed that the pollution assessment of the soils in the study area using diverse pollution assessment indexes (pollution index, pollution load index, ecological risk and risk index), based on the application of the local background value and the European average value, displayed a range of pollution levels due to differences in the threshold limits from differing geochemical background levels. The principal components analysis and positive matrix factorization, respectively, identified the sources of pollution and the distribution of PTE sources. Mapping the health index and total carcinogenic risk highlighted hotspots of areas within the study area that require immediate remediation. The self-organizing map ( $\mathrm{SeOM}$ ) revealed a diversified colour pattern for the factor scores. A single neuron exhibited a high hotspot in all factor loadings on different blocks of neurons. Children's CDItotal (Chronic Daily Intake total) values for non-carcinogenic risk and carcinogenic risk were found to be greater than adults', as were their $\mathrm{HQ}$ (hazard quotients) and CR (carcinogenic risk) values. According to the health index of non-carcinogenic risk, 6.1\% of the study area sampled posed a potential risk to children rather than adults. Corresponding to the sampled pointwise health risk assessment, $13.05 \%$ of the sampled locations are carcinogenic to children. The estimated health risk in
\end{abstract}

*Correspondence: agyeman@af.czu.cz

Department of Soil Science and Soil Protection, Faculty of Agrobiology,

Food and Natural Resources, Czech University of Life Sciences Prague,

16500 Prague, Czech Republic

\section{Springer Open}

(c) The Author(s) 2021, corrected publication 2021. Open Access This article is licensed under a Creative Commons Attribution 4.0 International License, which permits use, sharing, adaptation, distribution and reproduction in any medium or format, as long as you give appropriate credit to the original author(s) and the source, provide a link to the Creative Commons licence, and indicate if changes were made. The images or other third party material in this article are included in the article's Creative Commons licence, unless indicated otherwise in a credit line to the material. If material is not included in the article's Creative Commons licence and your intended use is not permitted by statutory regulation or exceeds the permitted use, you will need to obtain permission directly from the copyright holder. To view a copy of this licence, visit http://creativecommons.org/licenses/by/4.0/. 
the agricultural soil was high, with both carcinogenic and non-carcinogenic risks that could threaten persons living in the study area, particularly children.

Conclusion: In general, the continuous application of agriculturally related inputs such as phosphate fertilizers and other anthropogenic activities (e.g., steel industry) can increase the level of PTEs in soils. The use of mean, maximum, and minimum values in health risk estimation does not provide a comprehensive picture of a research area's health state. This study recommends using a sampled pointwise or location health risks assessment approach, which allows researchers to identify high-risk environments that exceeds the recommended threshold as well as areas on the verge of becoming high risk, allowing for rapid remedial action.

Keywords: Health risk, Source apportionment, Ecological risk, Spatial distribution, Principal component analysis, Selforganizing map

\section{Background}

Soil contamination suggests the presence of a chemical or foreign substance in concentrations above the normal threshold, which may be detrimental to an organism or humans [1]. This means of environmental pollution has become a primary ecological concern due to the timeless period of potentially toxic elements (PTEs) in nature coupled with the contamination of agricultural soils [2]. Although the more significant part of toxicity has anthropogenic origins, a few contaminants can typically happen in soils as components of weathering of rock deposits, and they can be toxic at high concentrations $[3,4]$. Furthermore, contamination of the soil periodically cannot be precisely assessed or seen outwardly, rendering it a latent threat.

Human health depends on a sustainable agricultural sector with minimum human interference, which acts as a forerunner to a sustainable healthy livelihood. However, agricultural soil directly impacts human health, and it is crucial for food safety; PTEs are the most hazardous contaminants due to their build-up in crops [5]. There exists a considerable volume of literature indicating that the accumulation of PTEs in the soil is not exclusively the result of anthropogenic phenomena, but rather the result of a collaborative effort between geogenic and anthropogenic activities [6-8]. Due to the agrochemical and industrial developments, the numerous contaminants are continually progressing. These pollutant varieties tend to form complexes with certain organic compounds in the soil and produce various metabolites through their biological activity. All of these are combined with the soil system and extracted through laboratory analysis. PTEs such as aluminium, arsenic, beryllium, cadmium, lead, mercury, nickel, and radium may have the ability to exude toxic effects that are hazardous to humans, such as carcinogenic effects, teratogenic effects, and endothelial dysfunction [9-11]. According to FAO and ITPS [1], the adverse impact of contaminants from agricultural soils, as they regulate the mobility, bioavailability, and residence of PTEs, depends on their properties, respectively.
These pollutants (PTE) have the potential to impact climate, soil, and water, as well as endangering organisms/ animals, humans, food security, health, and life [12]. However, according to Zukowska and Biziuk [13], the presence of PTEs in the ecosystem (e.g., vegetable soil) causes them to change from a solid-state to either ionic ligands or, via biomethylation to metallic organic moieties, which can be potentially hazardous to the health of humans, animals, and the entire eco-environment via the food chain. PTEs exhibits potential danger to human health owing to environmental contamination and are classified into two risk categories: carcinogenic and noncarcinogenic risk. Crentsil and Anthony [14] argued that health risk assessment is a high-profile methodology recognized as a valuable, critical method for identifying anthropogenic tendencies that are detrimental to human health. Chen et al. [15] indicated that a detailed understanding of the potential health risks posed by soil PTEs is necessary for informed decision-making by stakeholders to reduce contamination, reduce human exposure and protect humans from risk.

There is no question of the natural source of PTEs in agricultural soil. Regrettably, their increase in agricultural soils is a direct consequence of over-fertilization, which pollutes the soil with PTEs such as $\mathrm{Pb}, \mathrm{Cd}, \mathrm{Zn}, \mathrm{Ni}$, $\mathrm{Cu}$, as well as other polluting sources such as wastewater irrigation (As, $\mathrm{Pb}, \mathrm{Hg}, \mathrm{Cd})$, compost $(\mathrm{Pb}, \mathrm{Co}, \mathrm{Cd}, \mathrm{Zn})$, pesticide application $(\mathrm{Cd}, \mathrm{Pb}, \mathrm{Cu}, \mathrm{Zn})$, sub-standard fertilizer, and industrial activities $(\mathrm{Mn}, \mathrm{Ni}, \mathrm{As}, \mathrm{Pb}, \mathrm{Zn}, \mathrm{Cr}$, $\mathrm{Cu}, \mathrm{Cd})[16,17]$. It has been suggested by Kim et al. [18] and Yang et al. [19] that soil-bound PTEs risk assessment is based on metallic soil content, which may lead to inaccuracy and the necessity for costly remediation of soil. Its important to note, however, that PTEs contamination is not limited to agricultural land. Nevertheless, it may also be detected in living tissues, where it is, for the most part, irreparable [20]. Eziz et al. [21] and Mamut et al. [2] disclosed that PTEs might potentially cause havoc to humans, flora and fauna in the environment. Extensive study has been undertaken in the contemporary era in 
the disciplines of PTEs impact on human health, ecological risk, and highlighting environmental impacts [21-25]. Despite the abundance of literature on health concerns published worldwide, there is a dearth of documentation and research in the study area. However, according to Kampa and Castanas [26], health risk assessment is a practical and indispensable tool for recognizing and evaluating the dangers to human health caused by PTEs via various routes of exposure. The active agricultural production and number of industrial activities in the study area make monitoring human health exposure via PTEs critical. Indigenous health is a primary necessity in the study area. Hence a qualitative and comprehensive risk evaluation of agricultural soil health is necessary and appropriate. The primary objective of this paper is to create a digitized soil map that highlights the human-related health risks posed by PTEs, as well as to estimate and map pollution indices outputs, the pattern of PTE spatial distribution, source apportionment, and determine carcinogenic and non-carcinogenic health exposures using a sample location approach. This research will contribute significantly to the awareness of the dangers of PTE exposure in humans and livestock in the study area.

\section{Materials and methods \\ Study area}

The study site is located in the Czech Republic within the district of Frydek Mistek. Rugged terrain and mountains from the exterior Carpathians characterize the study area's geomorphology. The Carpathians, mountains and valleys are differentiated by natural rock and undulating relief. However, there are two mountain ranges in the northern section of the research region partitioned into highlands clusters by river valleys. The district's geological terrain is predominantly carbon-producing, making it an attractive shelter for Paskov and Staříc mining activities that are currently inactive [27].

The study area is characterized by extensive agricultural activity as well as various metal works (such as fabrication, pneumatic cylinders, valves, regulator, etc.) and steel industries (such as the production of cold-rolled steel strips and sheets, anisotropic electrical steel strips and sheets). It is geographically positioned at a latitude of $49^{\circ} 41^{\prime} 0^{\prime}$ North and a longitude of $18^{\circ} 20^{\prime} 0^{\prime}$ East at an altitude of 225-327 m above sea level [8]. Oilseeds, corn, sunflower, and grapevines are among the crops grown in the study area, as is the principal production of cereals such as wheat, oats, barley, and rye. Using the Koppen classification, the study area was classified as $\mathrm{Cfb}=$ oceanic temperate climate with high rainfall even during the dry months [28]. Throughout the year, the temperature ranges typically from $-5{ }^{\circ} \mathrm{C}$ to $24{ }^{\circ} \mathrm{C}$, with temperatures rarely falling below $-14{ }^{\circ} \mathrm{C}$ or rising over $30{ }^{\circ} \mathrm{C}$.
The average highest rainfall for the year is $83 \mathrm{~mm}$, with a minimum average total accumulation of $17 \mathrm{~mm}$ [29]. The estimated area for this study is $889.8 \mathrm{~km}^{2}$ extruded from a total land area of $1208 \mathrm{~km}^{2}$ (39.38\% for agronomic activities and forest land 49.36\%) for the district of Frydek Mistek. The soil's colour and its structure to its carbonate concentration of the soil's properties may be readily recognized from each other. The prevalent soils in the study area have bleached and paler coloration as well as dark colour in the topsoil. Nevertheless, the parent materials of the soil have a medium and fine texture. In most cases, they are found in aeolian and colluvial deposits, which are also characterized by mottles in the top and subsurface that can be seen in some soil regions, which are usually followed by concrete and whitening. A cambic diagnostic horizon distinguishes them with fine sandy loam texture, a clay concentration of more than $4 \%$, and a lithic discontinuity with reduced carbonate content [30]. Nevertheless, the prevalent soil types in the study are cambisols and stagnosols [30]. These soils predominate the Czech Republic and can be found at elevations ranging from 455.1 to $493.5 \mathrm{~m}$ [31].

\section{Soil sampling and analysis}

A total of 115 topsoil samples were collected from agricultural land in the district of Frydek Mistek (Fig. 1). The sampling pattern was a standard grid, and the soil samples distances remained $2 \times 2 \mathrm{~km}$ applying a hand-held GPS (Leica-Zeno 5 GPS) device at $0-20 \mathrm{~cm}$ deeper into the soil. The soil samples collected were deposited in Ziploc bags, categorized, and taken to the research laboratory. To obtain a pulverized soil sample, the obtained soil samples were air-dried before being crushed by a machine (Fritsch disk mill pulverize) and mesh sieved $(2 \mathrm{~mm})$. In the Teflon container, $1 \mathrm{~g}$ of the dried, homogenized, and sieved soil sample (sieve size $2 \mathrm{~mm}$ ) was placed and labelled. $7 \mathrm{ml}$ of $35 \% \mathrm{HCl}$ and $3 \mathrm{ml}$ of $65 \%$ $\mathrm{HNO}_{3}$ (use automatic dispensers-a special dispenser for each acid) were dispensed in each bottle of Teflon and gently closed the cap to enable the sample to remain overnight for reactions to take place (aqua regia procedure). The supernatant was placed on a hot metal plate for $2 \mathrm{~h}$ to promote digestion of the sample and left to cool when the soil sample was dissolved.

The supernatant was transferred into a prepared 50-ml volumetric flask and then diluted with deionized water to $50 \mathrm{ml}$. The diluted supernatant was then filtered into $50 \mathrm{ml}$ PVC tubes. In addition, $1 \mathrm{ml}$ of diluted concentration was further diluted with $9 \mathrm{ml}$ of deionized water and filtered into a $12 \mathrm{ml}$ test tube prepared to evaluate the pseudo-total PTE content. The ICP-OES (inductively coupled plasma optical emission spectrometry) (Thermo Fisher Scientific Corporation, USA) was utilized 


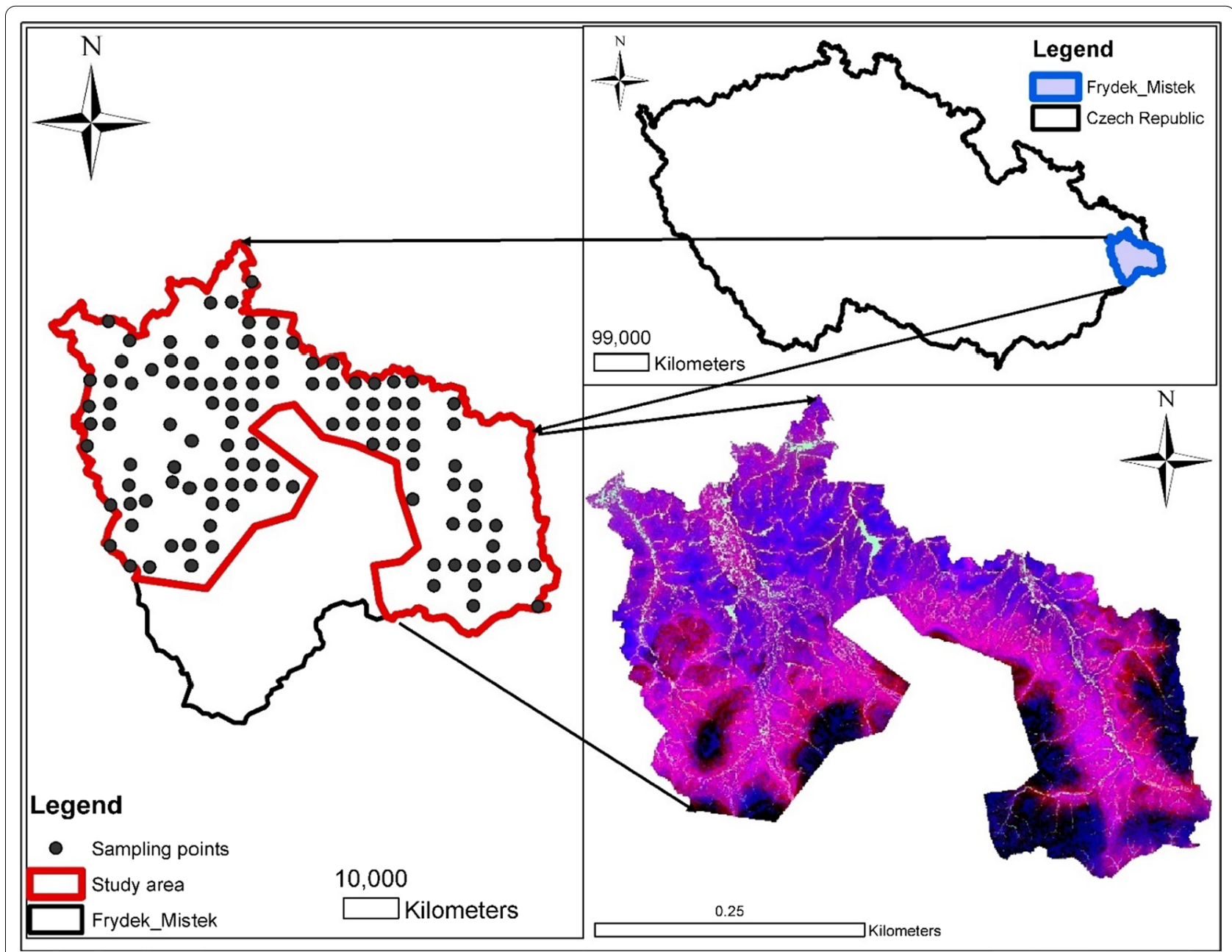

Fig. 1 Location map showing the sampled site with sampling points

to ascertain the concentration of PTEs $(\mathrm{Mn}, \mathrm{Ni}, \mathrm{As}, \mathrm{Pb}$, $\mathrm{Zn}, \mathrm{Cr}, \mathrm{Cu}, \mathrm{Cd}$ ) in compliance with standard procedures and protocols. Moreover, the quality control and quality assurance process were ensured by checking each sample's standards reference material (SRM NIST 2711a Montana II soil). The detection limits of the PTEs utilized in this study are $0.0002(\mathrm{Cd}), 0.0007(\mathrm{Cr}), 0.0060(\mathrm{Cu})$, $0.0001(\mathrm{Mn}), 0.0004(\mathrm{Ni}), 0.0015(\mathrm{~Pb}), 0.0067(\mathrm{As})$, and $0.0060(\mathrm{Zn})$. Duplicate analysis was carried out to ensure that the error was minimized. Pre-treatment analysis of soil samples was conducted at the Czech University of Life Science Prague.

\section{Pollution indices assessment}

The productive soil quality of agricultural land must be assessed to evaluate the effects and toxicity of PTE pollution. Based on this, various pollution indices such as the pollution index (PI), the pollution load index (PLI), the comprehensive ecological risk (ER) and the risk index (RI) were utilized to assess the pollution status of the study region. Huang et al., [32] and Sawut et al. [33] argue that indices can reliably measure the quality of soil contamination and the extent to which human activity impacts the soil environment. These indices are widely used in the assessment of PTE contamination in agricultural soil.

\section{Single pollution index (PI)}

The single pollution index (PI) is characterized as the concentration of PTE in a sample relative to its geochemical or geological background level. Tomlinson et al. [34] introduced the PI, and the equation is given as

$$
\mathrm{PI}=\frac{C_{n}}{B_{n}},
$$

where $B_{n}$ connotes the geochemical background values of the PTEs in the soil $(\mathrm{mg} / \mathrm{kg})$ and $C_{n}$ symbolizes the PTE 
concentrations in the soil $(\mathrm{mg} / \mathrm{kg})$. The PI precise scale is classified as $\mathrm{PI} \leq 1$ (low level), $1<\mathrm{PI} \leq 3$ (moderate level), $3<\mathrm{PI} \leq 6$ (considerable level) and $\mathrm{PI} \geq 6$ (high level).

\section{Pollution load index (PLI)}

The PLI is often used to measure the average amount of soil pollution. This index provides a direct way to display the soil deterioration resulting from the accumulation of PTEs. Tomlinson et al. [34] introduced this equation, and the equation is given as

$$
\mathrm{PLI}=\sqrt[n]{\mathrm{PI}_{1} \times \mathrm{PI}_{2} \times \mathrm{PI}_{3} \times \ldots \cdots \times \mathrm{PI}_{n}},
$$

where $n$ represents the number of analysed PTEs, PLI is categorized into four classes such as PLI $\leq 1$ (low level), $1<\mathrm{PLI} \leq 2$ (moderate level), $2<\mathrm{PLI} \leq 5$ (high level), or PLI $>5$ (extremely high level) centred on the intensity of pollution.

\section{Ecological risk assessment (ER and RI)}

Ecological risk (ER) is a measure employed to quantify the degree of ecological threat posed by PTE accumulation in soil. The index ER was pioneered and applied by Hakanson [35], and the equation is given as:

$$
E_{r}^{I}=T_{r}^{i} \times \text { PI. }
$$

The risk index (RI) is defined as the aggregate of each PTE's estimated ecological risk:

$$
\mathrm{RI}=\sum_{i=1}^{n} E_{r}^{i} .
$$

The $T_{r}^{i}$ is the toxicity response coefficient of specific PTE [34], and the PI represent the single pollution index. The toxicity response coefficient of the PTEs used are $30(\mathrm{Cd}), 10(\mathrm{As}), 5(\mathrm{Cu}), 5(\mathrm{~Pb}), 2(\mathrm{Cr}), 2(\mathrm{Zn})$, 2(Ni) and $1(\mathrm{Mn})$. The ER has 5 classifications: ER $\leq 40$ (low risk), $40<\mathrm{ER} \leq 80$ (moderate risk), $80<\mathrm{ER} \leq 160$ (considerable risk), $160<\mathrm{ER} \leq 320$ (high risk), and $E I \geq 320$ (very high risk). The RI has 4 classes, namely $\mathrm{RI} \leq 150$ representing the low risk, $150<\mathrm{RI} \leq 300$ indicating the moderate risk, $300<\mathrm{RI} \leq 600$ signifying the considerable risk and $\mathrm{RI}>600$ representing the very high risk.

\section{Positive matrix factorization (PMF) model}

The EPA-PMF v5.0 receptor model [36] is a multivariate receptor modelling approach used to estimate the contribution of the source of PTEs or hazardous substance samples to fingerprints or the composition of the source. The U.S. Environmental Protection Agency utilizes this receptor model, developed by Paatero [37];
Paatero and Tapper [38]. The model does not require any profile source, and all the data are weighted by using uncertainty. According to Norris et al. [39], PMF is used mainly in solving source contributions and source profile that is dataset composition based which is given by this equation:

$$
X_{i j}=\sum_{k=i}^{p}\left(g_{i k} f_{k j}+e_{i j}\right),
$$

in which $p$ represents the factor number, $f$ the source profile species, $g$ the sample contribution, $j$ and $i$ signifies the quantity of samples and chemical species, and $e_{i j}$ denotes the species.

This equation determines the contribution as well as profile factors:

$$
Q=\sum_{i=1}^{n} \sum_{j=1}^{m}\left(\frac{\varepsilon_{i j}}{u_{i j}}\right)^{2},
$$

in which $m$ represents the quantity of analysed PTEs, $n$ denotes the number of sampled soils, and $U_{i j}$ refers to the uncertainty of PTE $j$ in soil sample $i$. The parameters used to determine the uncertainty $U_{i j}$ and the minimum $Q$ were previously defined by the authors [8].

\section{Health risk assessment}

The ever-growing human population and human endeavour to ensure that the planet remains a haven for humanity are under constant constraint. Frequently, scientists, policymakers, and other stakeholders push the frontiers of research in many ways, and no matter the initiative and the best course of utilizing research, the world is now and then polluted. Humans are exposed to PTEs in three different forms every day, including inhalation, ingestion, and dermal contact. There are three procedures to assess the probability of human PTE exposure in peri-urban, urban, and rural settings, according to Wang et al. [40]. PTE exposure pathways to humans are calculated using the following equations:

$$
\begin{aligned}
& \mathrm{CDI}_{\text {ing }}=\frac{C \times \mathrm{IR}_{\text {ing }} \times \mathrm{EF} \times \mathrm{ED}}{\mathrm{BW} \times \mathrm{AT}} 10^{-6}, \\
& \mathrm{CDI}_{\text {inh }}=\frac{C \times \mathrm{IR}_{\text {inh }} \times \mathrm{EF} \times \mathrm{ED}}{\mathrm{PEF} \times \mathrm{BW} \times \mathrm{AT}}, \\
& \mathrm{CDI}_{\text {derm }}=\frac{C \times \mathrm{SA} \times \mathrm{AF} \times \mathrm{ABS} \times \mathrm{EF} \times \mathrm{ED}}{\mathrm{BW} \times \mathrm{AT}} \times 10^{-6},
\end{aligned}
$$




$$
\mathrm{CDI}_{\text {total }}=\mathrm{CDI}_{\text {ing }}+\mathrm{CDI}_{\text {inh }}+\mathrm{CDI}_{\text {derm }} \text {. }
$$

Additional file 1: Table S1 contains the definitions of the variables $\mathrm{CDI}_{\mathrm{ing}}, \mathrm{CDI}_{\mathrm{inh}}$, and $\mathrm{CDI}_{\mathrm{derm}}$, as well as reference values for the indices of the preceding Eqs. (7-10).

\section{Non-carcinogenic risk assessment}

The equation of the potential non-carcinogenic risk for a single PTEs was computed as the HQ (hazard quotient), which is given as Eq. (11):

$$
\mathrm{HQ}=\frac{\mathrm{CDI}}{\mathrm{RfD}}
$$

RfD (see Additional file 1: Table S1) represents the reference dose $(\mathrm{mg} / \mathrm{kg} / \mathrm{d})$, and it is the estimated daily human population exposure. The determination of a particular health hazard of all the PTEs analysed was done by computing HQ values. The sum of the values was reported as the HI (hazard index), which is provided as Eq. (12) [41]:

$$
\mathrm{HI}=\sum \mathrm{HQ}=\mathrm{HQ}_{\text {ing }}+\mathrm{HQ}_{\text {inh }}+\mathrm{HQ}_{\text {derm }},
$$

whereby $\mathrm{HQ}_{\text {ing }}, \mathrm{HQ}_{\text {inh }}$ and $\mathrm{HQ}_{\text {derm }}$ represent the hazardous quotient for inhaling, ingestion and dermal, respectively. A report from USEPA [42] explicitly outlined that when the $\mathrm{HI}<1$, it presupposes that there is a potential to negatively impact health if PTEs are exposed to humans. However, Eziz et al. [21] mentioned that if $\mathrm{HI}>1$, there is also the propensity for non-carcinogenic health risks to emerging.

\section{Carcinogenic risk assessment}

According to the USEPA's [41] findings, the possibility of developing cancer of any sort may be ascribed to humans being exposed to carcinogenic risk (CR). Equations (13 and 14) were employed to evaluate the carcinogenic risk of PTEs such as $\mathrm{As}, \mathrm{Ni}, \mathrm{Pb}, \mathrm{Cd}$, and $\mathrm{Cr}$ :

$$
\begin{aligned}
& \mathrm{CR}=\mathrm{CDI} \times \mathrm{SF}, \\
& \mathrm{TCR}=\sum \mathrm{CR}=\mathrm{CR}_{\text {ing }}+\mathrm{CR}_{\text {inh }}+\mathrm{CR}_{\text {derm }},
\end{aligned}
$$

in which the variables TCR, CR, and SF reflect total carcinogenic risk (no unit), carcinogenic risk (no unit), and slope factor for carcinogenic PTEs $(\mathrm{mg} / \mathrm{kg} / \mathrm{d})$, respectively. TCR values should be in the range of $1 \times 10-6$ to $1 \times 10-4$. That is a reasonable standard that demonstrates no considerable risk to human health [43]. All the exposure factor values utilized in the health risk calculation are listed in Additional file 1: Table S1.

\section{Analysis of data}

The data were statistically analysed using kyplot for principal component analysis, RStudio for projected principal component loadings, EPA-PMF 5.0 to estimate source apportionment, and excel in quantifying the potential health risk as well as Pearson correlation matrix. PTE modelling, spatial distribution maps, and health risk assessment were interpolated using ordinary kriging in an R software environment. The factor scores of the PMF receptor model were likewise mapped using a self-organizing map (SeOM).

Kohonen [44] created SeOM by combining an artificial neural network with unsupervised learning techniques for organizing, evaluation, and predictions. SeOM was employed in this study to visualize factor score contribution as well as determine the number of clusters within the factor scores of the PMF receptor model in an agricultural urban and peri-urban soil. The SeOM assessment data act as an input dimensional vector variable [45, 46]. Melssen et al. [47] defined a neural network as having a single input layer that connects an input vector to a vector output with a unitary weight vector. SeOM generates a two-dimensional map composed of several neurons or nodes knitted together into a hexagonal, circular, or square topological layout based on their closeness [45]. Based on metrics, topographic error (TE) and quantization error $(\mathrm{QE})$, map sizes were examined, and a SeOM model with 0.086 and 0.904 was chosen as a 55 -map unit $(5 \times 11)$. The neuron structure was selected based on the empirical equation node number, which was given as:

$$
m=5 \times \sqrt{n},
$$

in which the $m$ denotes the quantity of SeOM map neurons, $\mathrm{n}$ representing the input data quantity.

\section{Results and discussion \\ PTEs concentration in soil}

Statistical standards such as mean, median, skewness and kurtosis, standard deviation were employed to detect the PTEs concentration levels in the sampled soil (see Table 1). Table 1 includes PTEs estimated mean concentrations of the UCC (upper continental crust), WAV (world average values), and EAV (European average values) reported by Kabata-Pendias [48]. PTE concentrations ( $\mathrm{Zn}, \mathrm{Pb}, \mathrm{Mn}, \mathrm{Cr}, \mathrm{Cu}, \mathrm{As}, \mathrm{Ni}, \mathrm{Cd}$ ) varied from 186.02 to $1691.76 \mathrm{mg} / \mathrm{kg}(\mathrm{Mn}), 37.48$ to $272.18 \mathrm{mg} /$ $\mathrm{kg}(\mathrm{Zn}), 9.56$ to $155.69 \mathrm{mg} / \mathrm{kg}(\mathrm{Pb}), 10.9$ to $62.78 \mathrm{mg} /$ $\mathrm{kg}(\mathrm{Cr}), 7.88$ to $62.62 \mathrm{mg} / \mathrm{kg}(\mathrm{Cu}), 4.86$ to $42.39 \mathrm{mg} / \mathrm{kg}$ $(\mathrm{Ni}), 1.85$ to $30.42 \mathrm{mg} / \mathrm{kg}$ (As) and 0.61 io $7.28(\mathrm{Cd}) \mathrm{mg} /$ $\mathrm{kg}$. In the agricultural soil, the concentration of PTEs declined in the following order: $\mathrm{Mn}>\mathrm{Zn}>\mathrm{Pb}>\mathrm{Cr}>\mathrm{C}$ $\mathrm{u}>\mathrm{Ni}>\mathrm{As}>\mathrm{Cd}>($ see Table 1$)$. The general PTEs mean 
Table 1 PTE concentrations in the study site, basic data, toxic element, and geochemical background levels (number sample 115 per each PTE)

\begin{tabular}{|c|c|c|c|c|c|c|c|c|}
\hline & \multirow[b]{2}{*}{$\mathrm{Mn}$} & \multirow[b]{2}{*}{$\mathrm{Ni}$} & \multicolumn{3}{|c|}{ PTEs (mg/kg) } & \multirow[b]{2}{*}{$\mathrm{Cd}$} & \multirow[b]{2}{*}{$\mathrm{Cr}$} & \multirow[b]{2}{*}{$\mathrm{Cu}$} \\
\hline & & & $\mathrm{Pb}$ & $\mathrm{Zn}$ & As & & & \\
\hline Mean & 699.03 & 16.15 & 33.86 & 85.22 & 5.32 & 1.84 & 28.43 & 22.54 \\
\hline Median & 664.39 & 13.75 & 30.10 & 75.47 & 4.57 & 1.61 & 26.90 & 19.68 \\
\hline Local background value $\mathrm{A}^{\mathrm{A}}$ & - & 30.00 & 50.00 & 80.00 & - & 0.20 & 70.00 & 25.00 \\
\hline Finland $^{B}$ & - & 60.00 & 60.00 & 150.00 & 10.00 & 0.50 & 100.00 & 100.00 \\
\hline Austria ${ }^{C}$ & - & 35.00 & 30.00 & 100.00 & - & 0.40 & 54.00 & 35.00 \\
\hline Spain $^{D}$ & - & 25.50 & 26.50 & 57.00 & 14.00 & - & 57.00 & 17.50 \\
\hline Sweden & 411.00 & 13.00 & 18.00 & 65.00 & 3.80 & 0.17 & 22.00 & 17.00 \\
\hline Japan & - & 26.00 & 24.00 & 89.00 & - & 0.33 & 58.00 & 48.00 \\
\hline Brazil & 535.00 & 25.00 & 22.00 & 73.00 & - & 0.18 & 86.00 & 109.00 \\
\hline USA & 550.00 & 19.00 & 19.00 & 60.00 & 7.20 & $<0.01-41$ & 54.00 & 25.00 \\
\hline UCC $^{b}$ & 900.00 & 20.00 & 15.00 & 70.00 & 1.80 & 0.10 & 100.00 & 17.30 \\
\hline WAV ${ }^{\mathrm{a}}$ & 488.00 & 29.00 & 27.00 & 70.00 & 6.83 & 0.41 & 59.50 & 38.90 \\
\hline EAV & 524.00 & 37.00 & 32.00 & 68.10 & 11.60 & 0.28 & 94.80 & 17.30 \\
\hline Minimum & 186.02 & 4.86 & 9.56 & 37.48 & 1.85 & 0.61 & 10.90 & 7.88 \\
\hline Maximum & 1691.76 & 42.39 & 155.69 & 272.18 & 30.42 & 7.28 & 62.78 & 62.62 \\
\hline Range & 1505.74 & 37.53 & 146.13 & 234.70 & 28.57 & 6.67 & 51.88 & 54.74 \\
\hline Standard Deviation & 259.35 & 6.78 & 18.51 & 34.35 & 4.95 & 1.01 & 9.38 & 9.98 \\
\hline Kurtosis & 1.37 & 2.49 & 18.80 & 7.32 & 11.77 & 10.45 & 2.69 & 4.90 \\
\hline Skewness & 0.79 & 1.63 & 3.67 & 2.11 & 3.04 & 2.84 & 1.33 & 2.04 \\
\hline CV\% & 39.04 & 49.29 & 61.51 & 45.52 & 108.23 & 62.86 & 34.88 & 50.71 \\
\hline
\end{tabular}

${ }^{a}$ World average value (WAV)

b Upper continental crust (UCC)

'European average value (WAV), [48] (page 41 and 42), coefficient of variability (CV) A [51], B [109], C [110], D [111]

concentration in the soil was relatively high than the EAV threshold, specifically $\mathrm{Pb}, \mathrm{Mn}, \mathrm{Zn}, \mathrm{Cd}$, and $\mathrm{Cu}$. In the current study, the mean value of cadmium is 6.57 times greater than that of EAV (see Table 1), as are the concentrations of $\mathrm{Mn}$ (1.33), $\mathrm{Pb}$ (1.06), $\mathrm{Cu}$ (1.06), and $\mathrm{Zn}$ (1.06), (1.33). Although there may be a geogenic source, evidence suggests that anthropogenic activities significantly compensate for the elevation in PTE concentrations. Toth [49] reported some PTEs thresholds from the Ministry of Environment Finland (MEF), and $\mathrm{As}(5.0 \mathrm{mg} / \mathrm{kg})$ and $\mathrm{Cd}(1.0 \mathrm{mg} / \mathrm{kg})$ threshold limits were lower than the current study's corresponding PTEs. The mean concentration of $\mathrm{Cr}(100.0 \mathrm{mg} / \mathrm{kg})$, $\mathrm{Cu}(100.0 \mathrm{mg} / \mathrm{kg}), \mathrm{Pb}(60.0 \mathrm{mg} / \mathrm{kg}), \mathrm{Ni}(50.0 \mathrm{mg} / \mathrm{kg})$, and $\mathrm{Zn}(200.0 \mathrm{mg} / \mathrm{kg})$ from the MEF threshold limits, on the other hand, was found to be greater than the respective PTEs mean concentration from the current study.

Conversely, the mean concentrations of the following PTEs, like $\mathrm{Pb}, \mathrm{Mn}, \mathrm{Zn}$, and $\mathrm{Cd}$, in our current study are similarly greater than the same PTEs from the world average value (WAV) threshold limit [48] (see Table 1). PTEs $(\mathrm{Mn}, \mathrm{Pb}, \mathrm{Zn}$, and $\mathrm{Cd}$ ) concentration levels in the current study are $1.48,1.25,1.21$, and 4.49 times greater than WAV concentration threshold. Similarly, when the PTEs studied mean concentration values were compared to the PTEs of the UCC (Table 1), it was discovered that $\mathrm{Zn}, \mathrm{Pb}, \mathrm{Cd}$ and $\mathrm{As}$ are higher than the respective PTEs in the UCC. Comparatively, the mean concentration levels of $\mathrm{Zn}, \mathrm{Pb}, \mathrm{Cd}$ and As surpassed those of UCC by 2.26 , $1.55,3.57$ and 18.4 times respectively.

The present study indicated that elevated values of some PTEs than those of UCCs indicate that anthropogenic sources play a vital role in pollution. The assertion is compatible with Jia et al. [50] point of view. The present mean concentration of PTEs in the current research relative to the mean concentration of PTEs in Sweden [48] suggests that the concentration of PTEs exceeded the threshold limits of the PTEs in Sweden (see Table 1). A comparable comparison to PTEs concentration levels reported in Brazil and the United States [48] shows that the following PTEs, $\mathrm{Mn}, \mathrm{Pb}, \mathrm{Zn}$, and $\mathrm{Cd}$, are lower than those reported in the present study (see Table 1). Comparing the concentration values of PTEs with those obtained from Japan [48] revealed that most of the PTEs under analysis were lower than those from Japan, except 
for $\mathrm{Pb}$ and $\mathrm{Cd}$ (see Table 1). The current mean values of the PTEs (Ni, As, and $\mathrm{Cr}$ ) in the study area were found to be lower when compared to the agricultural soil threshold limits in Finland, Austria, and Spain. On the other hand, $\mathrm{Pb}, \mathrm{Zn}$, and $\mathrm{Cd}$ levels in the current study were higher than the respective PTEs from Spain, but lower than the corresponding threshold limits from Finland and Austria. Cadmium mean concentrations in the present study were significantly higher than the threshold limit (see Table 1) from Finland and Austria. Predicated on the Nemecek and Podlesakova [51] report, the local background values (LBV) for $\mathrm{Ni}, \mathrm{Pb}, \mathrm{Cr}$, and $\mathrm{Cu}$ from the district of Frydek Mistek revealed that the mean concentration of PTEs was within the permissible threshold limit (see Table 1). However, the mean concentrations of $\mathrm{Cd}$ and $\mathrm{Zn}$ in the study were higher than the local background values reported by Nemecek and Podlesakova [51] (see Table 1).

The estimated standard deviation values were high due to the concentration of PTEs with high variable heterogeneity in the study region. The computed skewness values were used to determine the normality and abnormalities of the distribution of PTEs values. According to Chandrasekaran et al. [52], if the PTE skew value ranges from 1 to -1 , it can be viewed as a regular distribution. Notwithstanding, if the PTE value is slightly skewed positively $(>1)$, the distribution is anomalous. The calculated kurtosis and skewness values were usually greater than 1 ; thus, the distribution of PTEs is believed to be irregular, skewed in the right direction and leptokurtic.

The CV (coefficient of variation) represents the extent of heterogeneity within PTE concentrations, pursuant to Karimi Nezhad et al. [53]. If the CV is between 0 and $20 \%$, it is assumed that the PTEs are from a natural source, and if it is greater than $20 \%$, it indicates the influence of anthropogenic activity. As a result, a CV of $20 \%$ shows low variability, a $\mathrm{CV}$ of $50 \%$ indicates moderate variability, a $\mathrm{CV}$ of $50 \%$ indicates significant variability, and a CV of $100 \%$ suggests extraordinarily high variability. The CV of the PTEs in the present agricultural soils declined in the following order $\mathrm{As}>\mathrm{Cd}>\mathrm{Pb}>\mathrm{Cu}>\mathrm{Ni}>$ $\mathrm{Zn}>\mathrm{Mn}>\mathrm{Cr}$. The results evidenced that the PTEs Cr, $\mathrm{Zn}, \mathrm{Mn}$, and $\mathrm{Cr}$ are moderately variable and homogeneous. The high variability of $\mathrm{Cd}, \mathrm{Pb}$, and $\mathrm{Cu}$ inferred a non-homogeneous variability of PTEs, clearly indicating that the possible human-related influence. Arsenic (As) showed a very abnormal CV suggesting an exceptionally high variability. According to the distribution of $\mathrm{Cd}, \mathrm{Pb}$, and $\mathrm{Cu}$ non-spatial homogeneity, there is a likely local source of enrichment substance.
Table 2 Principal component illustrating the contributions of PTEs in the study area

\begin{tabular}{lcr}
\hline PTEs & PC1 & PC2 \\
\hline $\mathrm{Mn}$ & 0.621 & 0.195 \\
$\mathrm{Ni}$ & 0.497 & 0.709 \\
$\mathrm{~Pb}$ & 0.877 & -0.306 \\
$\mathrm{Zn}$ & 0.872 & -0.076 \\
$\mathrm{As}$ & 0.788 & -0.491 \\
$\mathrm{Cd}$ & 0.907 & -0.311 \\
$\mathrm{Cr}$ & 0.501 & 0.288 \\
$\mathrm{Cu}$ & 0.577 & 0.667 \\
Eigenvalues & 4.191 & 1.506 \\
\% variance explained & 52.38 & 18.83 \\
cumulative \% total & & 71.21 \\
\hline
\end{tabular}

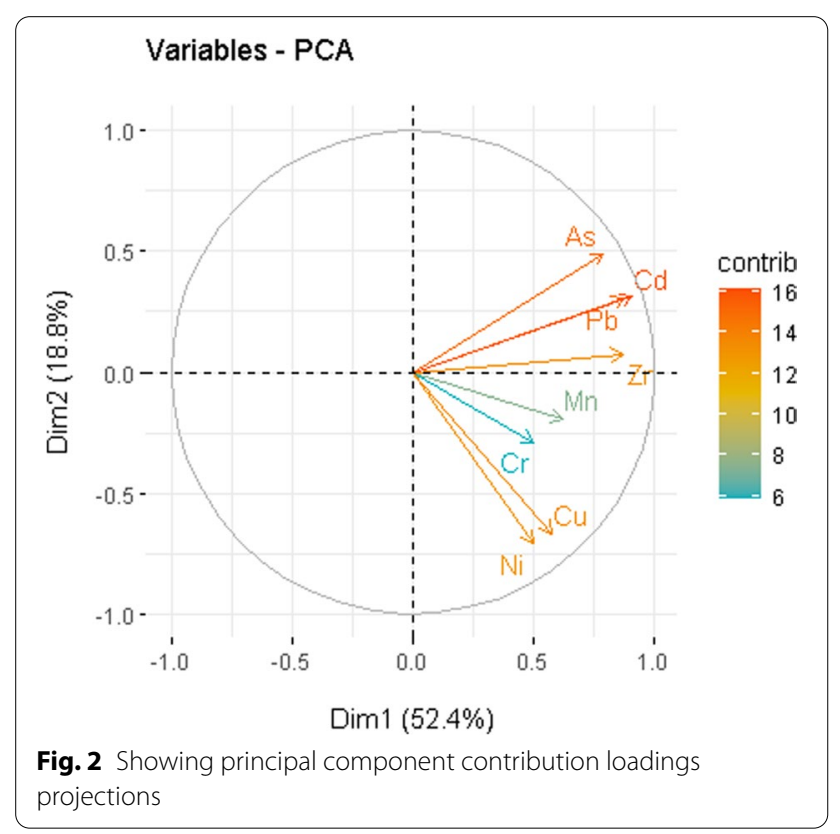

\section{Chemometric approach Multivariate analysis of PTEs}

The primary source of pollution in the study area was detected utilizing principal component analysis (PCA). It is a supportive approach that can make valuable suggestions about PTE paths and primary sources [54]. The loadings of the principal components (PCs) extracted from the principal correlation values were fixed at or above 0.50 in this study (Table 2; Fig. 2). Following the criterion, PC 1 and PC 2 were statistically significant, accruing $71.21 \%$ of the data variance. PC1 explained $52.38 \%$ of the variance explained by the PTEs $\mathrm{Pb}, \mathrm{Zn}, \mathrm{As}, \mathrm{Mn}, \mathrm{Cr}$, and $\mathrm{Cd}$, in that order. According to the report in Table 2, some of the PTEs ( $\mathrm{Pd}, \mathrm{Zn}, \mathrm{As}$, and $\mathrm{Cd}$ ) in PC1 had a 
strong positive load ranging from 0.7 to 0.9 , while other tenants, such as $\mathrm{Mn}$ and $\mathrm{Cr}$, had a moderate positive load (0.5-0.7). This indicated that PC1 concentrations might be attributable to a variety of sources, including anthropogenic and parental material components. Agrochemicals such as lead arsenate herbicides or pesticides, which are essential sources of agricultural soil chemicals, are agronomically linked to $\mathrm{As}$ and $\mathrm{Pb}$ [55]. Existing studies by Nicholson et al. [56] and Luo et al. [57] established that livestock manure and fertilizer are important sources of As and $\mathrm{Pb}$. The findings of the current study support this statement. The origins of $\mathrm{Zn}$ and $\mathrm{Mn}(r$ values $=0.872$ and 0.621 , respectively) may be traced back to the convergence of anthropogenic and geogenic sources (liming). According to Mantovi et al. [58], Zn concentration in soil surges may be linked to the application of waste resulting from animal husbandry and phosphate fertilizers. $\mathrm{Cd}$ and $\mathrm{Cr}$ accumulation in soils are related to the forging of metal, sewage and chemical fertilizers [59-62]. PC2 (18.83\% of the overall variance) showed relatively high positive loading for PTEs such as $\mathrm{Cu}$ and $\mathrm{Ni}$. As a result, $\mathrm{Cu}$ and Ni have a comparable source of pollution. $\mathrm{Cu}$ concentrations in topsoil are probably caused by fertilizers, other agricultural pollutants, and urban waste [63]. The presence of Nickel (Ni) in soil originates from both the parent material (lithosphere) and the anthropogenic deposition [64].

The correlation matrix (see Table 3) among the studied PTEs demonstrated the existence of a relationship between the PTEs. PTEs correlation revealed a strong relationship between the PTEs. Pb (lead) and $\mathrm{Zn}$ (zinc) demonstrated a strong positive connection with $\mathrm{PbAs}(r$-value $=0.75)$, AsCd $(r$-value $=0.9), \mathrm{CdPb}$ $(r$-value $=0.85)$, and CdZn $(r$-value $=0.78)$. As a result, it is critical to emphasize that they may have the same or nearly analogous origins. Other correlations between PTEs, such as As and $\mathrm{Zn}(r$-value $=0.63)$ and $\mathrm{Ni}$ and $\mathrm{Cu}$ $(r$-value $=0.69)$, likewise exhibited a robust nexus, indicating that the pollution cause might be correlated or close together. $\mathrm{Cd}$ and As had the highest correlation value, while $\mathrm{Ni}$ and As had the least positive correlation $(r$-value $=0.07)$. All the PTEs had a positive relationship and no negative correlation.

\section{Spatial distributions of PTEs in the study area}

The PTEs spatial distributions in the study area are depicted in Fig. 3. As and $\mathrm{Cd}$ shared the same distribution map pattern, likewise $\mathrm{Cr}$ and $\mathrm{Mn}$. The distribution pattern of As and Cd primarily was centred in the eastwards and the south-eastern area of the map. The map shows hotspots around the eastern (i.e. the steel industry) and the south-eastern part, but the As distribution map appears to be denser than $\mathrm{Cd}$. Spatial variability of $\mathrm{Cu}$ and $\mathrm{Ni}$ showed hotspots across the northwestern, southwestern, and south-eastern parts of the map. The source distribution of $\mathrm{Cu}$ and $\mathrm{Ni}$ spatially in the map may be attributed to the steel industry and agrochemicals; this is coherent with the earlier study carried out by Krishna and Govil [65].

Moreover, Salonen and Korkka-Niemi [66] identified certain PTEs such as $\mathrm{Ni}$ and $\mathrm{Cu}$ as minute spatial and temporal distribution in world soils present in parent soil materials. Furthermore, $\mathrm{Cr}$ and $\mathrm{Mn}$ showed more undulated spatial distribution across the entire map except for the south-eastern part that looks relatively clean. $\mathrm{Cr}$ spatial variability appears to be denser than that of $\mathrm{Mn}$. The abundance of $\mathrm{Cr}$ is caused by a variety of human-related activities such as electroplating. In addition, the industrial utilization of chromium in alloy creation, such as the steel industry and sewage discharge, are responsible for the Cr hotspots on the map. According to Goovaerts [67], the source of PTEs such as Cr, the geochemical/geological background of $\mathrm{Cr}$ is normal in generally. Nonetheless, its accumulation in agricultural soils may well be altered by anthropogenic sources related at times. Even though $\mathrm{Mn}$ is naturally occurring, the regular injection of manganese sulphate to farmland to boost yields in plants such as veggies and beans continuously raises

Table 3 Showing the correlation matric between PTEs

\begin{tabular}{llllllll}
\hline & Mn & Ni & Pb & Zn & As & Cd & Cr \\
\hline $\mathrm{Mn}$ & 1.00 & & & & & & \\
$\mathrm{Ni}$ & 0.24 & 1.00 & & & & & \\
$\mathrm{~Pb}$ & 0.42 & 0.21 & 1.00 & & & & \\
$\mathrm{Zn}$ & 0.38 & 0.45 & 0.83 & 1.00 & & & \\
$\mathrm{As}$ & 0.38 & 0.07 & 0.75 & 0.62 & 1.00 & & \\
$\mathrm{Cd}$ & 0.43 & 0.30 & 0.85 & 0.78 & 0.90 & 0.00 & 1.00 \\
$\mathrm{Cr}$ & 0.49 & 0.27 & 0.28 & 0.27 & 0.25 & 0.34 & 0.29 \\
$\mathrm{Cu}$ & 0.40 & 0.69 & 0.35 & 0.44 & 0.16 & 0.31 & 1.00 \\
\hline
\end{tabular}



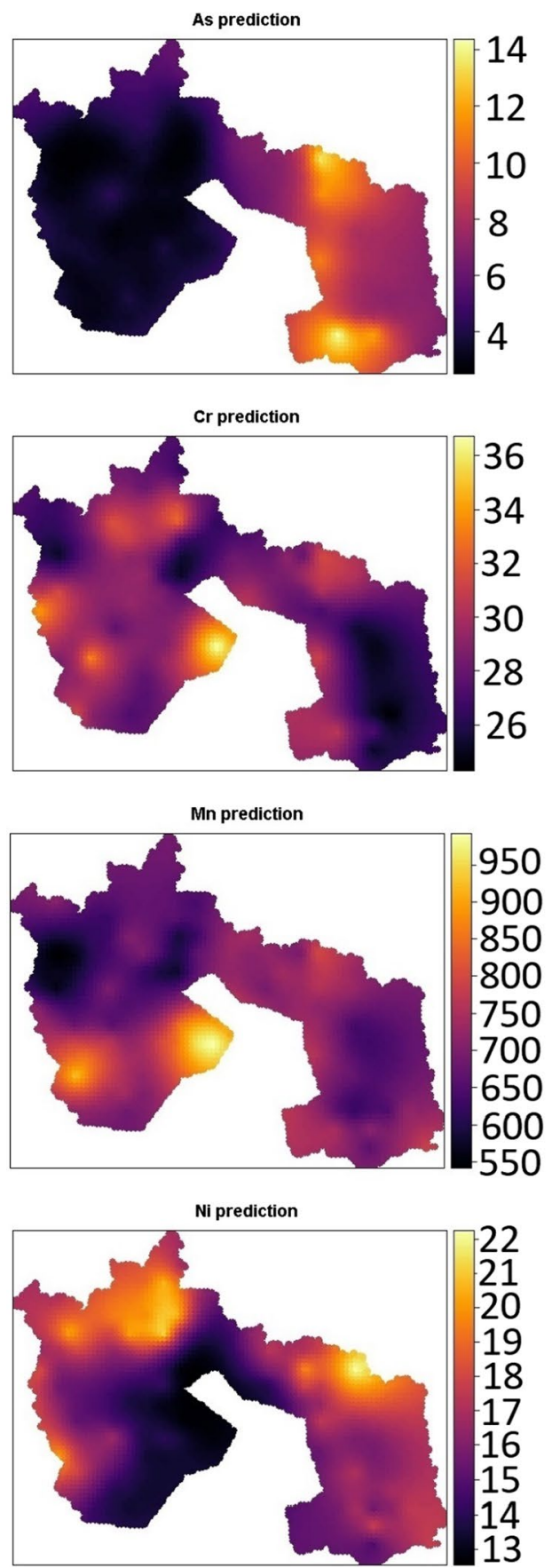

Fig. 3 The spatial distribution of PTEs in agricultural soil
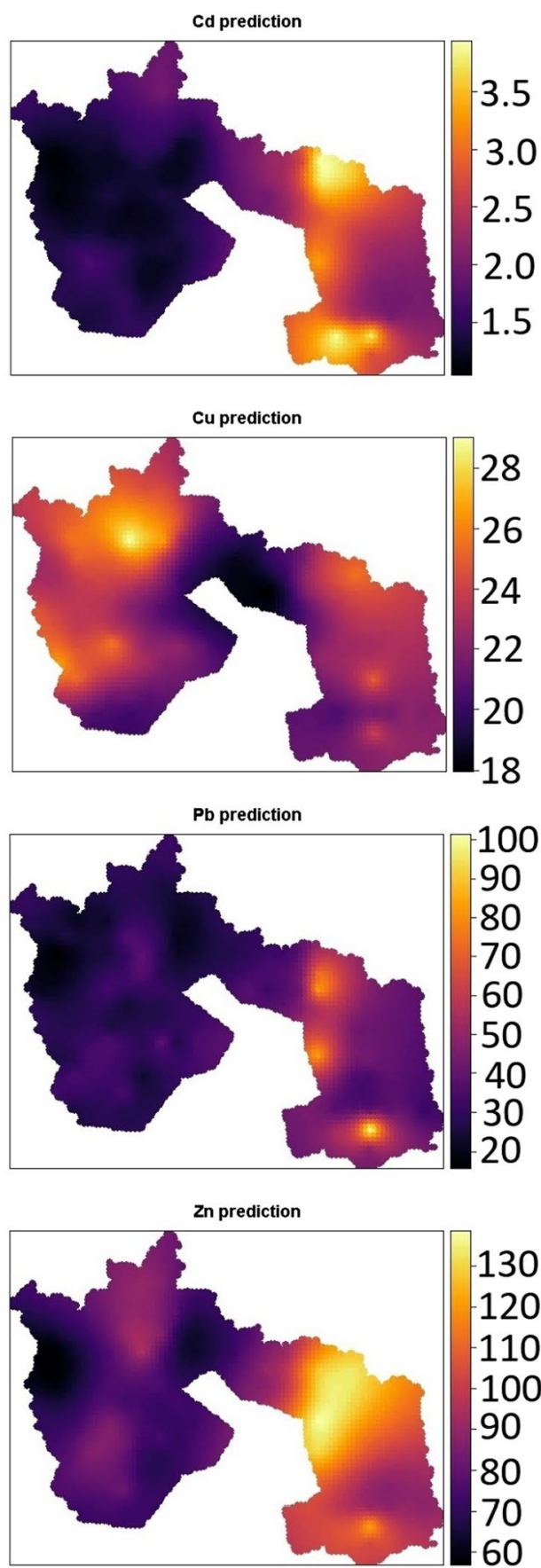

the concentration of PTEs [68]. The eastern and southeastern areas of the map exhibited a sectorial spatial pattern distribution of $\mathrm{Zn}$ and $\mathrm{Pb}$. The distribution of $\mathrm{Pb}$ and $\mathrm{Zn}$ spatially is linked directly to fertilizer application on farmlands, vehicular traffic, steel industry, and fuel knocking, which is consistent with the preceding study by Rodriguez et al., [69] stating that elevated levels of $\mathrm{Zn}$ and $\mathrm{Pb}$ in cultivated soil are due to anthropogenic factors composed by human-associated activities.

\section{Source apportionment via PMF}

The source apportionment of PTE contributions was performed applying the PMF receptor model, and the total number of samples included in the PMF analysis for each 


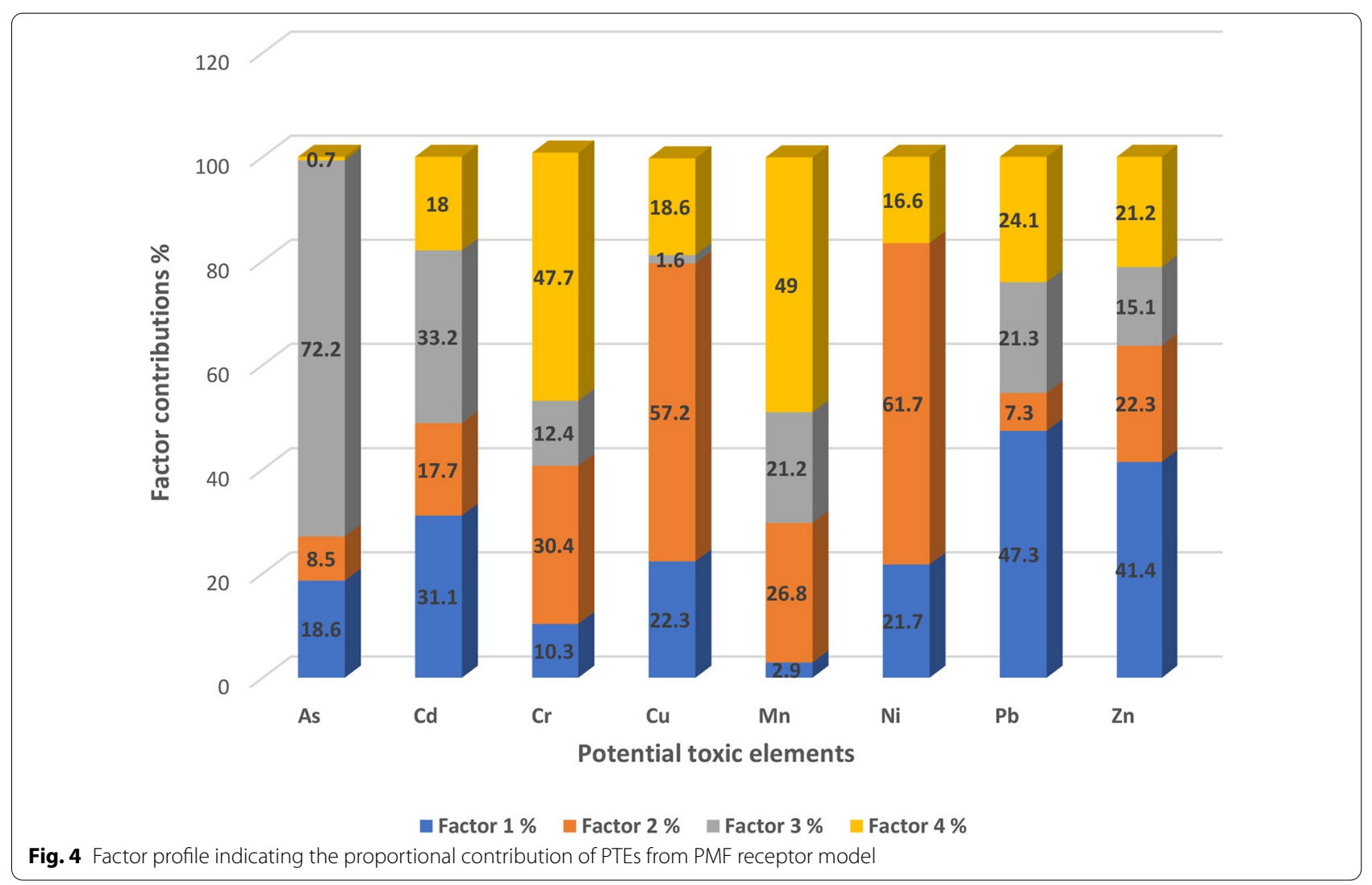

PTE was 115 (see Fig. 4). The minimum Q controls the residual matrix, which guarantees that an acceptable number of factors are generated. The PMF discharged factors loading that ran for twenty iterations, and all of the minimal Q converge in the current paper. Among the 20 iterations, run 14 was chosen to discharge the factor loadings and the proportional contributions of each PTE in the study. For a PTE to dominate a factor loading, the percentage dominant was fixed at $40 \%$ or more.

Factor 1 provided high factor loadings values comprising $\mathrm{Pb}$ and $\mathrm{Zn}$ (47.3\% and $41.4 \%$, respectively). The predominance of $\mathrm{Pb}$ and $\mathrm{Zn}$ in agricultural soil can be traced primarily to several sources. The dominant PTEs $(\mathrm{Pb}$ and $\mathrm{Zn})$ in factor 1 are principally anthropogenic origin, evidenced by the projected principal component contribution loadings (Fig. 2) and have a strong correlation. They have elevated mean concentrations above the regulated thresholds, that is, WAV and EAV. Chakraborty et al. [70] and Khosravi et al. [71] reported that $\mathrm{Zn}$ and $\mathrm{Pb}$ are the principal PTEs pollutants in peri-urban and urban agricultural soil. The high level of $\mathrm{Pb}$ in the agricultural fields may be attributable to vehicular traffic, abrasion of tyres, knocking of fuel, and a limited geogenic source. Earlier reports from Tepanosyan et al. [72] and Li et al. [73] suggested that $\mathrm{Pb}$ accumulation in the soil may be attributable to automotive traffic, fuel knocking, and abrasion tyres. Similarly, Arditsoglou and Samara, [74] Hjortenkrans et al. [75] and Guan et al. [76] reported that $\mathrm{Pb}$ is deposited throughout agricultural fields via road networks used by automobile machines that connect vicinities, suburbs, and farmlands, where automobiles, agricultural-based machinery, and discharge equipment's which is $\mathrm{Pb}$-containing exhaust, triggering soil pollution. Nevertheless, the source of $\mathrm{Zn}$ in the soil might be accredited to the steel industry within the study area and the wearing of vehicular tyres. Al-Khashman and Shawabkeh [77] and Wang et al. [78] recounted that the level of $\mathrm{Zn}$ in the soil might be attributable to the steel industry and tyre wearing. The metal and steel industries employ a high amount of $\mathrm{Zn}$, which is generally used as an anti-corrosive agent in other metal products and exhibits galvanizing and alloy forming properties. Therefore, factor 1 source of pollution will be ascribed to the blend of the steel industry and vehicular traffic.

Factor 2 was controlled by $\mathrm{Cu}$ and $\mathrm{Ni}$, accounting for $57.2 \%$ and $61.7 \%$ factor loading, respectively. The hotspots on Factor 2 spatial distribution map indicated that the $\mathrm{Cu}$ and $\mathrm{Ni}$ hotspots in the northwest enclave originated primarily from agricultural activities. The PCA projection in Fig. 2 suggests that the source of $\mathrm{Ni}$ and $\mathrm{Cu}$ 
in the farmlands is mostly linked towards the geogenic origin. Nevertheless, $\mathrm{Cu}$ excess beyond the EAV also hints at a collaborative effort between geogenic sources and anthropogenic sources such as livestock manure. Copper accretion is correlated chiefly to cattle manure [79] because the confluence of $\mathrm{Cu}$ and $\mathrm{Zn}$ functions as a complement (anti-bacterial agent in the gut) [80], which boosts microbial activity and also modulates weaning patterns [81]. The application of $\mathrm{Cu}$-rich manure (especially from livestock like pigs) and phosphate-based fertilizers, according to Cheng et al., [82] and Xiong et al. [79], may perhaps ultimately lead to $\mathrm{Cu}$ accumulation in agricultural soil. Even though Ni concentrations in agricultural area may be attributed to a geogenic source, the high levels recorded at specific sample locations are confirmed by the spatial distribution map (Fig. 3), demonstrating that the steel industry is the polluting catalyst. According to Al-Khashman [77] and Harasim and Filipek [83], the steel and metal industries, food processing, tyre wear, vehicular traffic, and corrosion appear to be the sources of Ni contamination. Numerous reports like Li et al. [84] and Chen et al. [85] have indicated that $\mathrm{Ni}$ arises through manufacturing activities such as steel manufacturing and metal processing. Ni plays a vital function in the creation of alloys such as nickel stain (a tin and nickel alloy), silver (a copper, nickel, zinc) and nickel bronze alloy (a tin and copper solution). Factor 2 pollution will primarily be attributable to geogenic sources, which will be bolstered by steel production industries and livestock manure.

Factor 3 was overshadowed by As, which had a source contribution of $72.2 \%$. Most insecticides, herbicides, and pesticides, like sodium arsenate, calcium arsenate and lead arsenate, are high in arsenic and used in a variety of agricultural applications. Bhattacharya et al. [86] discovered that agrochemicals of this sort, such as sodium arsenate, calcium arsenate and lead arsenate, are high inorganic As. In previous research, Micó et al. [87] and Nicholson et al. [56], Jayasumana et al. [88, 89] suggested that the potential sources of As-enrichment in soil are agrochemicals. Furthermore, Liu et al. asserted that animal wastes containing organo-arsenic feed additives constitute a significant source of arsenic pollution in agricultural fields due to concentrated animal feeding activities. Factor 3 source of pollution will be ascribed to agrochemicals.

$\mathrm{Cr}$ and $\mathrm{Mn}$ controlled the final factor (factor 4) with a contribution load of $47 \%$ and $49 \%$, respectively. Thus, the chromium concentration in the agricultural field might be attributed to a geogenic source. However, in some sampled locations, excesses based on maximum values also point to an anthropogenic source supplementing the geogenic source. In addition, the consistent application of phosphate fertilizer to the soil during each crop season introduces $\mathrm{Cr}$ into the soil, raising the concentration of $\mathrm{Cr}$ in farmlands. Liu et al. [90] recounted that the concentration of $\mathrm{Cr}$ per bag of phosphate fertilizer ranges from 30 to $3000 \mathrm{mg} / \mathrm{kg}$. Nonetheless, current literature by Zhang et al. [91] indicated that high-level Cr concentrations in cultivated soils that exceed the permissible threshold limit are not limited to agro-related sources but rather a blend of parental material and anthropogenic sources. The mean concentration of $\mathrm{Mn}$ in the current agricultural soils is 1.43 and 1.33 times greater than the WAV and the EAV permissible threshold. This suggested that the high levels might be attributed to a diverse source such as the steel industry and fungicides. According to Bradl [92] $\mathrm{Mn}$ is used in the steel industry to produce ferromanganese steel. However, Shaw [93] reported that fungicides had been an integral component of plant disease management regimens for agronomic crops. Fungicides are applied to agricultural fields to prevent or limit the spread of fungus-caused disease. The successive application of manganese-based fungicides such as foliar fertilizers to increase yield elevates $\mathrm{Mn}$ concentration in agricultural soil. Factor 4 source pollution will be linked to a geogenic source that is actively augmented by the steel industry and fungicides.

The shown self-organizing map (SeOM) illustrates the concentration of PTEs in the PMF factor loadings as component planes composed of individual neurons. The component plane exhibited diverse colour patterns, as shown in Fig. 5. Based on the number of samples used in this study, the suitable neurons per mapped map was 55. The SeOMs were created with various colours, and the more similar the colour pattern, the more identical the sample attributes. Factor 1 and 3 components plane bore a striking resemblance in colour to the neighbour distance plot (U-Matrix). Factor 1 component plane was loaded with dominant PTEs such as $\mathrm{Pb}$ and $\mathrm{Zn}$ with a single high neuron on the left side of the map on the sixth block of neurons. Factor 2 component plane was loaded with the dominant PTEs $\mathrm{Cu}$ and $\mathrm{Ni}$, exhibiting moderate to high neurons. The high neuron was envisaged on the fourth block of neurons of the map. Factor 3 was loaded with dominant PTE such as As, and the high neuron equally was seen on the Fourth block of neurons. Factor 4 was controlled by the PTEs like $\mathrm{Mn}$ and $\mathrm{Cr}$, and the SeOM displayed a variety of colour shades from mild to moderate, moderate to a high neuron. The high neuron was seen on the tenth neurons block.

Generally, a redder colour neuron was displayed in the SeOMs. The component plane of the factor1 SeOM map showed a hotspot for the dominant PTEs. The proportion of $\mathrm{Pb}, \mathrm{Zn}, \mathrm{Cd}$, and $\mathrm{As}$ is predominantly anthropogenic in origin, accounting for $70.76 \%$ of factor 1 loading, confirming that $\mathrm{SeOM}$ for the factor 1 component plane is 


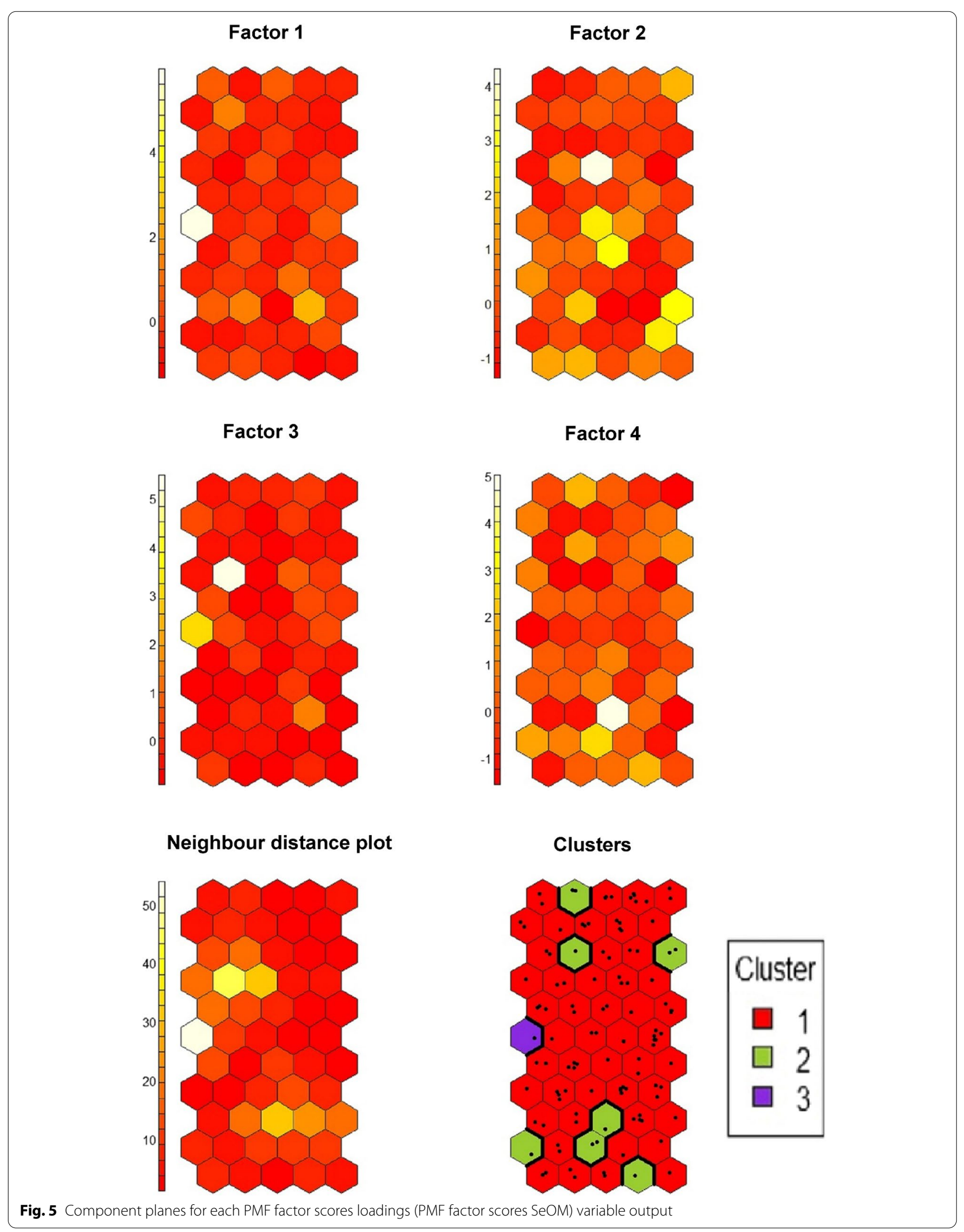




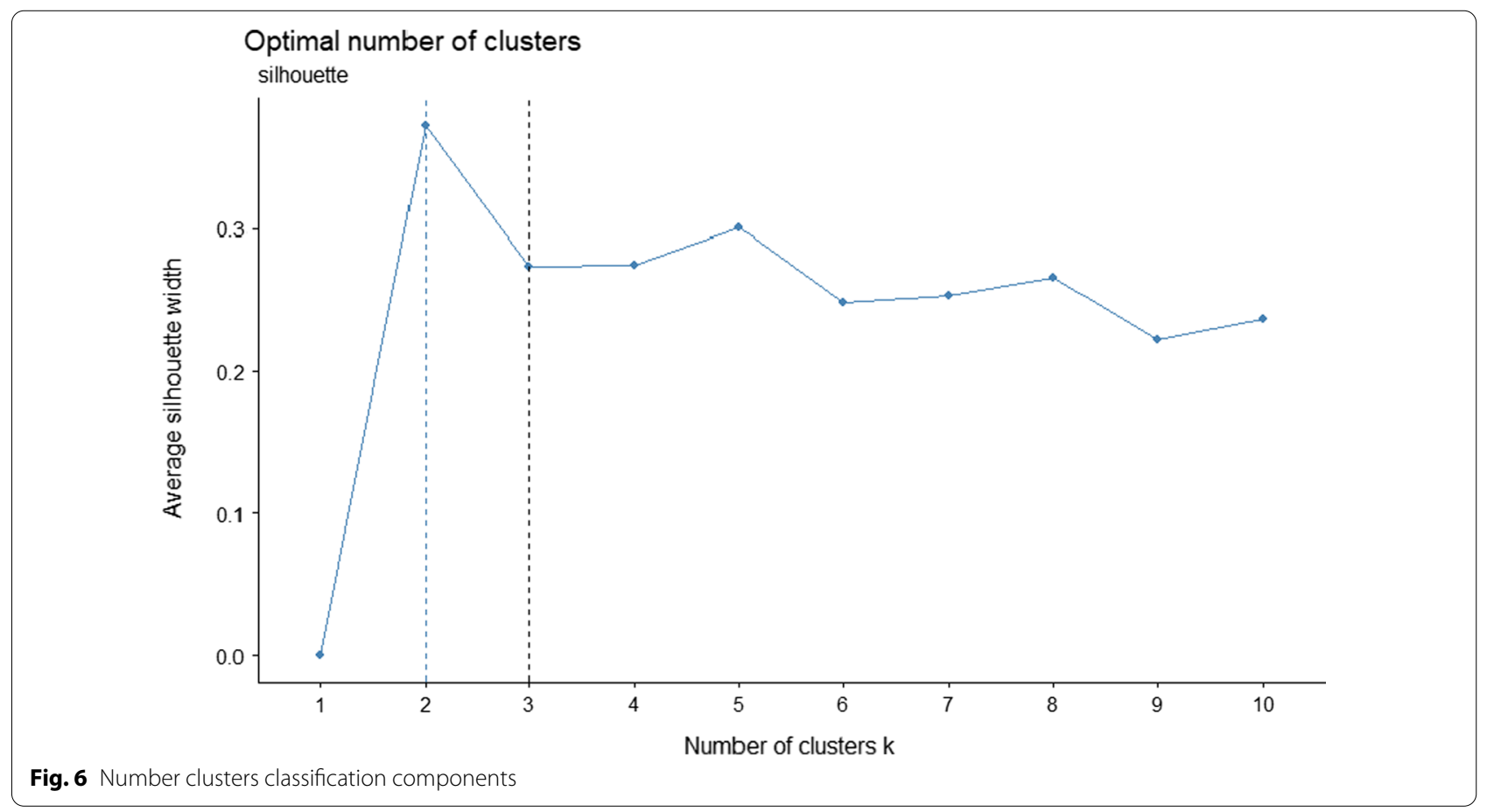

primarily anthropogenic. Factor 2 percentage proportion was dominated by geogenic PTEs $(\mathrm{Ni}, \mathrm{Cu}, \mathrm{Mn}$, and $\mathrm{Cr})$, which accounted for $75.94 \%$ of the cumulative variation. The factor 2 component plane was more geogenic due to the significant percentage proportion accrued by $\mathrm{Ni}, \mathrm{Cu}$, $\mathrm{Mn}$, and $\mathrm{Cr}$ in factor 2 loading. Based on the PTEs $(\mathrm{Pb}$, $\mathrm{Zn}, \mathrm{Cd}$, and As) percentage proportion (80.11\%) accumulated, the factor $3 \mathrm{SeOM}$ component plane is more anthropogenic. Based on the percentage proportion (67.33\%) accrued by the PTEs (Ni, Cu, Mn and $\mathrm{Cr}$ ), factor 4 component plane was ascribed to geogenic source.

$\mathrm{K}$-means (silhouette) on the training map resulted in three distinct clusters $(1-3)$. The partitioned three clusters developed using the K-means technique are displayed in distinct colours that correspond to the U-Matric component plane boundaries. Based on the silhouette technique (see Fig. 6), the cluster was ideal. The four-factor component planes represent the four-factor loadings in the PMF receptor model, which is simplified to allow for appropriate clustering interpretation [94]. The clustering of the 115 observation points allotted sampled points as follows; cluster 1 gathered the most soil samples, 102, out of a total of 115 , cluster 2 received 12 samples, but Cluster 3 only obtained 1 (see Fig. 6). Due to the diverse anthropogenic and natural processes that influence soil formation, it is complicated to have appropriately differentiated cluster patterns in the distributed map [95].

\section{Contamination assessment of PTEs based on local} background (LBV) and European average values (EAV) LBV and EAV were the geochemical background levels used in assessing pollution levels in the study area. The PTEs employed in the LBV, on the other hand, were $\mathrm{Cd}$, $\mathrm{Cu}, \mathrm{Cr}, \mathrm{Ni}, \mathrm{Pb}$, and $\mathrm{Zn}$, and the EAV As, $\mathrm{Cd}, \mathrm{Cu}, \mathrm{Cr}, \mathrm{Ni}$, $\mathrm{Mn}, \mathrm{Pb}$, and $\mathrm{Zn}$. However, a comparison of pollution levels based on PI, PLI, ER, and RI was performed using the associated PTEs in both background levels.

Additional file 1: Table S2 shows the calculated single pollution index (PI) for the EAV, and the results suggested that the pollution level of the PTEs ranged from low to high. Mn pollution was observed in 22 of the 115 soil samples and As in 86, when PI was measured using EAV. Some of the locations sampled had a moderate level of pollution, and 92 of the areas sampled had a moderate level of Mn and As (67). (i.e. using the EAV). Manganese and arsenic pollution levels were high in a single observation location (sampled point 18 for $\mathrm{Mn}$ ) and in 3 sampled areas for As. The PI for the following PTEs was estimated using both EAV and LBV as the geochemical background values: $\mathrm{Cd}, \mathrm{Cu}, \mathrm{Cr}, \mathrm{Zn}, \mathrm{Ni}$, and $\mathrm{Pb}$ (see Additional file 1: Tables S2 and S5). Nickel, lead, zinc, chromium, and copper levels were low when EAV was used as the geochemical background level in 106, 44, 44, 113, and 108 sampled locations. Based on LBV as the geochemical background level, the number of sampled locations 106, 105, 61, 115 and 84 exhibited low pollution levels for the following PTEs $\mathrm{Cu}, \mathrm{Cr}, \mathrm{Zn}, \mathrm{Ni}$, and $\mathrm{Pb}$. In $\mathrm{EAV}, \mathrm{Ni}, \mathrm{Pb}, \mathrm{Zn}, \mathrm{Cd}, \mathrm{Cr}$, 
and $\mathrm{Cu}$ showed moderate pollution levels in 9, 67, 70, 29, 2 , and 7 sampled locations, respectively, whereas, in LBV, moderate pollution levels were found in 9, 9, 27, 84 and 53 sampled locations, except for $\mathrm{Cr}$, which showed none. In comparison, $\mathrm{Pb}, \mathrm{Zn}$, and $\mathrm{Cd}$ pollution levels estimated using EAV suggested that $\mathrm{Pb}, \mathrm{Zn}$, and $\mathrm{Cd}$ exhibited a considerable pollution level in 4,1 and 73 sampled locations, respectively, whereas using LBV just a single sampled location showed a significant pollution level for $\mathrm{Pb}$ and $\mathrm{Zn}$, and 27 for $\mathrm{Cd}$. The number of sampled locations with high levels of $\mathrm{Cd}$ pollution in the study area was 13 based on EAV and 88 based on LBV.

The estimated pollution load index (PLI) exhibited a varied response for both background levels; however, all background levels revealed low pollution levels in 104 locations for EAV and 103 locations for LBV. Furthermore, for 7 locations, both background values showed moderate pollution. Only 3 locations had high pollution levels for EAV and 4 for LBV, but one (sample point 104 with PLI value 498: see Additional file 1: Table S4) had very high pollution levels for both background levels. The spatial distribution patterns of the pollution level based on both background levels were comparable (Fig. 7). The PLI maps revealed moderate pollution levels with patches of the hotspot and low spots in the south-eastern part of the map. These hotspots are consistent with the observed high PI values.

The ecological risk (ER) approach was utilized to examine the influence of various PTEs on cultivated soils. Except for $\mathrm{Cd}$, the results of the ER assessment of cultivated soil samples indicated a low-risk analysis for all PTEs $(\mathrm{Ni}, \mathrm{Pb}, \mathrm{Zn}, \mathrm{Cr}$, and $\mathrm{Cu})$ in both background levels used (see Additional file 1: Tables S3 and S6). Based on the background levels application, 15 of the 115 analysed locations revealed a moderate ecological risk level for the EAV, but none showed a moderate ecological risk level for LBV. On the other hand, 13 locations exhibited a considerable ecological risk level for LBV and the EAV 77 observed locations. Based on the background levels, the high ecological risk level was 78 for the LBV and 19 for the EAV. In contrast, both background levels exhibited very high ecological risk in 24 for LBV and 4 for EAV for the background levels in sampled locations, respectively.

The calculated risk index of the study region also indicated that 3 sampled locations had low ecological risk levels for LBV and 64 for EAV (see Additional file 1: Table S4). Relatively, the LBV and EAV exhibited moderate ecological risk levels in 70 and 44 sampled locations, respectively. Similarly, the risk index based on the application of the LBV as the geochemical background level revealed that 36 of the sampled locations were considerably risky, whereas the EAV, 6 sampled locations were considerably risky. Only 6 of the sampled locations had a very high ecological risk for the LBV, while EAV a sample location exhibited high ecological risk. The RI-OK (risk index ordinary kriging) spatial distribution map revealed that the majority of the risk-prone areas were in the northeastern and southwestern parts of the map for the potential ecological risk index based on EAV (PERI-EAV) and the northwestern to southwestern parts of the map for the potential ecological risk index based on LBV (PERI-LBV) (Fig. 8). According to the maps, the underlying cause of pollution in that region may be mostly traced to industrial and agricultural activities. The PLI and RI values for agricultural soils in Frydek Mistek's district indicated that pollution levels range from low PTE pollution to very high pollution risk. As a result, it's critical to identify PTE pollution sources on agricultural soil. LBV use is recommended, particularly
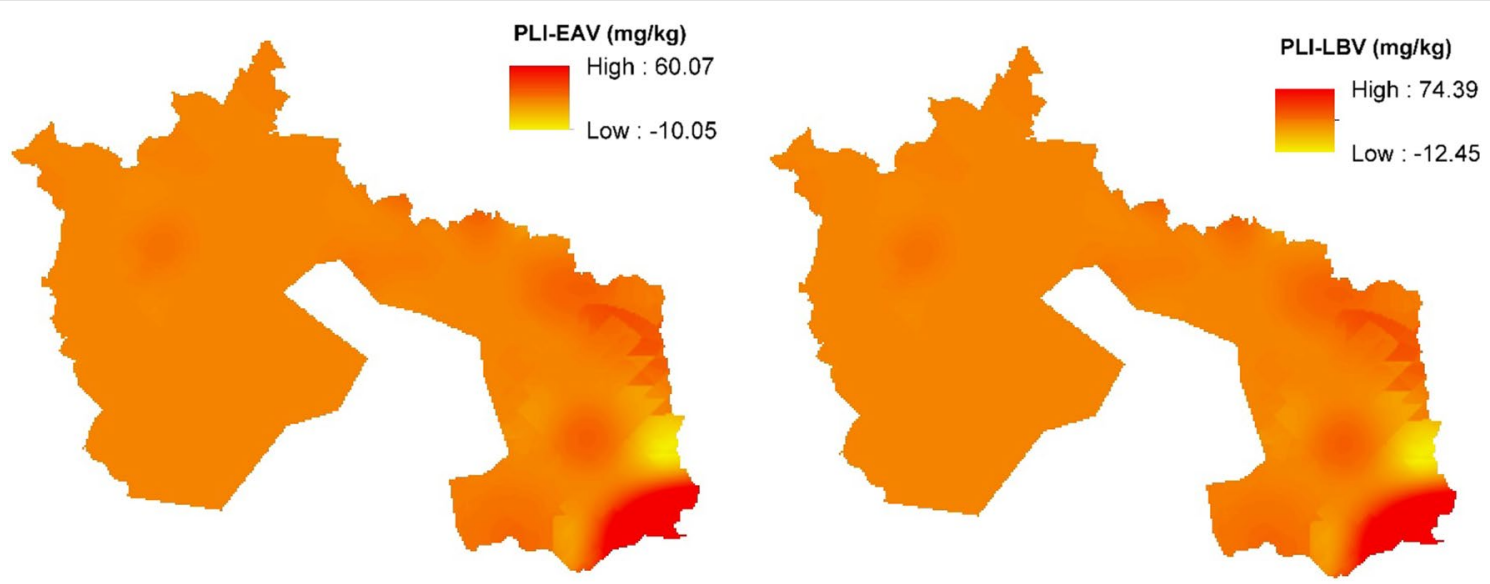

Fig. 7 Spatial distribution of PLI_OK (pollution load index kriging) displaying the levels of pollution for $\mathrm{Ni}, \mathrm{Pb}, \mathrm{Zn}, \mathrm{Cd}, \mathrm{Cr}$ and $\mathrm{Cu}$ in the study area 


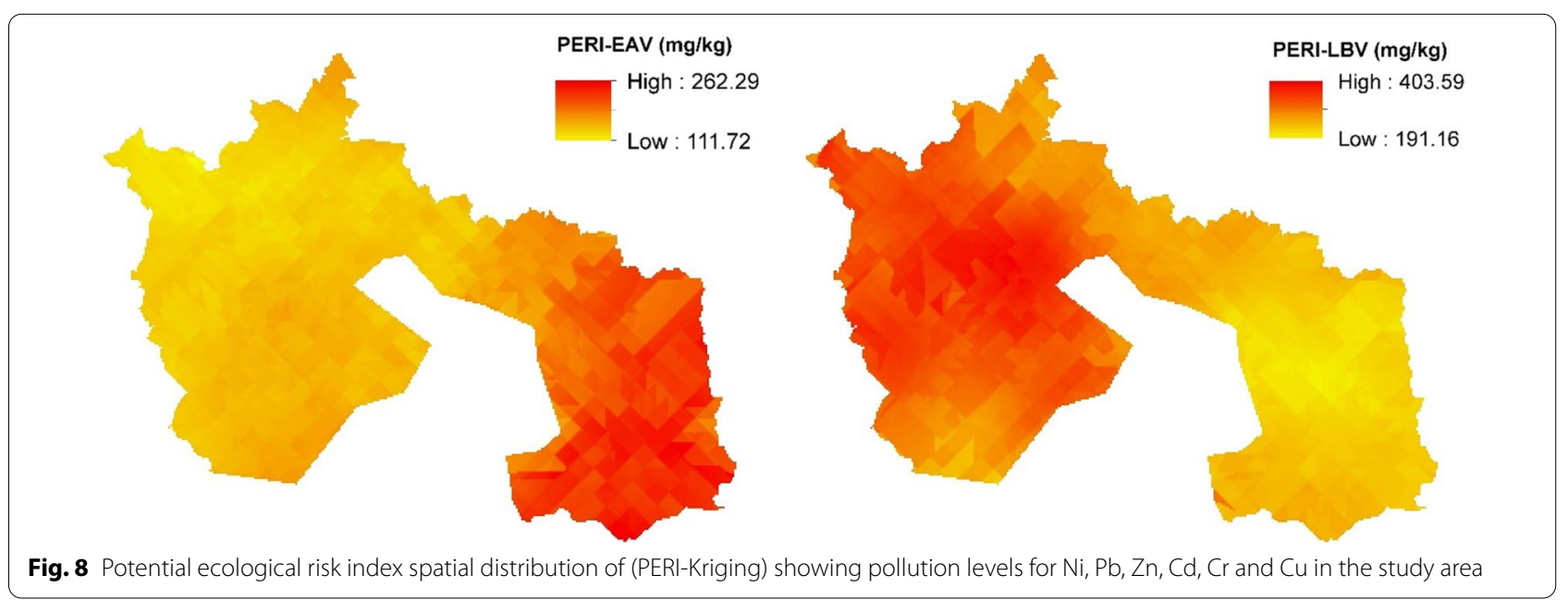

when anthropogenic impacts and high levels of pollution are anticipated, because these levels might vary significantly among lithogenic contexts and should be examined in pedologically and geologically homogeneous areas [96]. However, using a reference geochemical background (e.g., EAV, UCC, and WAV) in the quantification of pollution level allows information about soil quality assessment to be analysed on a worldwide scale, enabling comparative studies beyond the local scale, and pollution indices that require reference geochemical background in their computation to be more multipurpose [96, 97].

\section{Potential human health risk Non-carcinogenic risk}

The computed $\mathrm{CDI}_{\text {totals }}$, HQ and HI values for non-Carcinogenic risk are displayed in Additional file 1: Tables

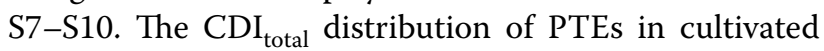
soils in the current research (children and adults) is presented in the following decreasing order: $\mathrm{Mn}>\mathrm{Zn}>\mathrm{Pb}>$ $\mathrm{Cr}>\mathrm{Cu}>\mathrm{Cd}>\mathrm{Ni}>\mathrm{As}$ (see Additional file 1: Tables $\mathrm{S} 4$ and S5). Additional file 1: Tables S4 and S5 illustrate the total non-carcinogenic intake $\left(\mathrm{CDI}_{\text {total }}\right)$ of adults and children. The CD total values for children compared to adults indicate that children are slightly higher than adults. The $\mathrm{CDI}_{\text {total }}$ of the PTEs per sampled data (see Additional file 1: Table S7 and S8) suggested that the children exposure rate is higher than that of the adults. However, the children's computed hazard quotient (HQ) appears to be higher than the adults HQ (Additional file 1: Tables S9-S10). Based on the maximum and minimum range values of the HQs of children and adults per PTE, which fall between the following ranges such as $4.90 \mathrm{E}-02$ to $2.82 \mathrm{E}-01(\mathrm{Cr}), 3.12 \mathrm{E}-03$ to $2.72 \mathrm{E}-02(\mathrm{Ni}), 2.53 \mathrm{E}-03$ to $2.01 \mathrm{E}-02(\mathrm{Cu}), 7.91 \mathrm{E}-02$ to $1.30 \mathrm{E}+00(\mathrm{As}), 1.70 \mathrm{E}-02$ to
$1.55 \mathrm{E}-01(\mathrm{Mn}), 3.51 \mathrm{E}-02$ to $5.72 \mathrm{E}-01(\mathrm{~Pb}), 1.60 \mathrm{E}-03$ to $1.16 \mathrm{E}-02(\mathrm{Zn})$ and $8.42 \mathrm{E}-03$ to $1.01 \mathrm{E}-01(\mathrm{Cd})$ for children whereas the adults are $5.37 \mathrm{E}-03$ to $3.10 \mathrm{E}-02$ (Cr), 3.34E-04 to $2.92 \mathrm{E}-03(\mathrm{Ni}), 2.71 \mathrm{E}-04$ to $2.15 \mathrm{E}-03$ $(\mathrm{Cu}), 8.48 \mathrm{E}-03$ to $1.39 \mathrm{E}-01(\mathrm{As}), 1.82 \mathrm{E}-03$ to $1.66 \mathrm{E}-02$ (Mn), 3.77E-03 to $6.14 \mathrm{E}-02(\mathrm{~Pb}), 1.72 \mathrm{E}-04$ to $1.25 \mathrm{E}-03$ $(\mathrm{Zn})$ and $9.19 \mathrm{E}-04$ to $1.10 \mathrm{E}-02(\mathrm{Cd})$. The calculated HQs values for PTEs of the minimum and maximum values (both children and adults) descend in this order As $>$ $\mathrm{Pb}>\mathrm{Cr}>\mathrm{Mn}>\mathrm{Cd}>\mathrm{Ni}>\mathrm{Cu}>\mathrm{Zn}$. The findings confirmed that ingestion was the most probable route for people in the study area to be exposed to PTEs. The variability of the measured PTEs concentration per sampled location revealed that the $\mathrm{HI}$ (for children) values estimated per $2 \times 2 \mathrm{~km}$ suggested that 7 of the sampled location were higher than 1 . Nonetheless, the HI estimated also suggested that $6.1 \%(1.01 \mathrm{E}+00$ to $2.05 \mathrm{E}+00$ that is 7 out of 115 sampled locations) of the total study area posed a high non-carcinogenic risk to children (see Additional file 1: Table S9). Similarly, $13.04 \%$ of the entire sampled area (i.e. $0.704-0.90$, or 15 out of 115 for children) is on the verge of exceeding the allowable threshold if remedial action is not undertaken (see Additional file 1: Table S9). Children are more vulnerable to the health impacts of PTEs due to oral and finger practice, according to Agyeman et al. [98], and appear to be highly susceptible to PTEs. Numerous studies that employ PTE mean values to determine the risk to human health have consistently confirmed a High HI or lower risk level. Children's HI values in some studies that reported high or low $\mathrm{HI}$ values for children are as follows: Agyeman et al. [98] Han et al. [99], Natasha et al. [100], Wang et al. [101], Bhandari et al. [102] and Zheng et al. [103]. The computed HI for the adult is not statistically significant considering it is lower than the reference value 1 ; it thus implies that if 

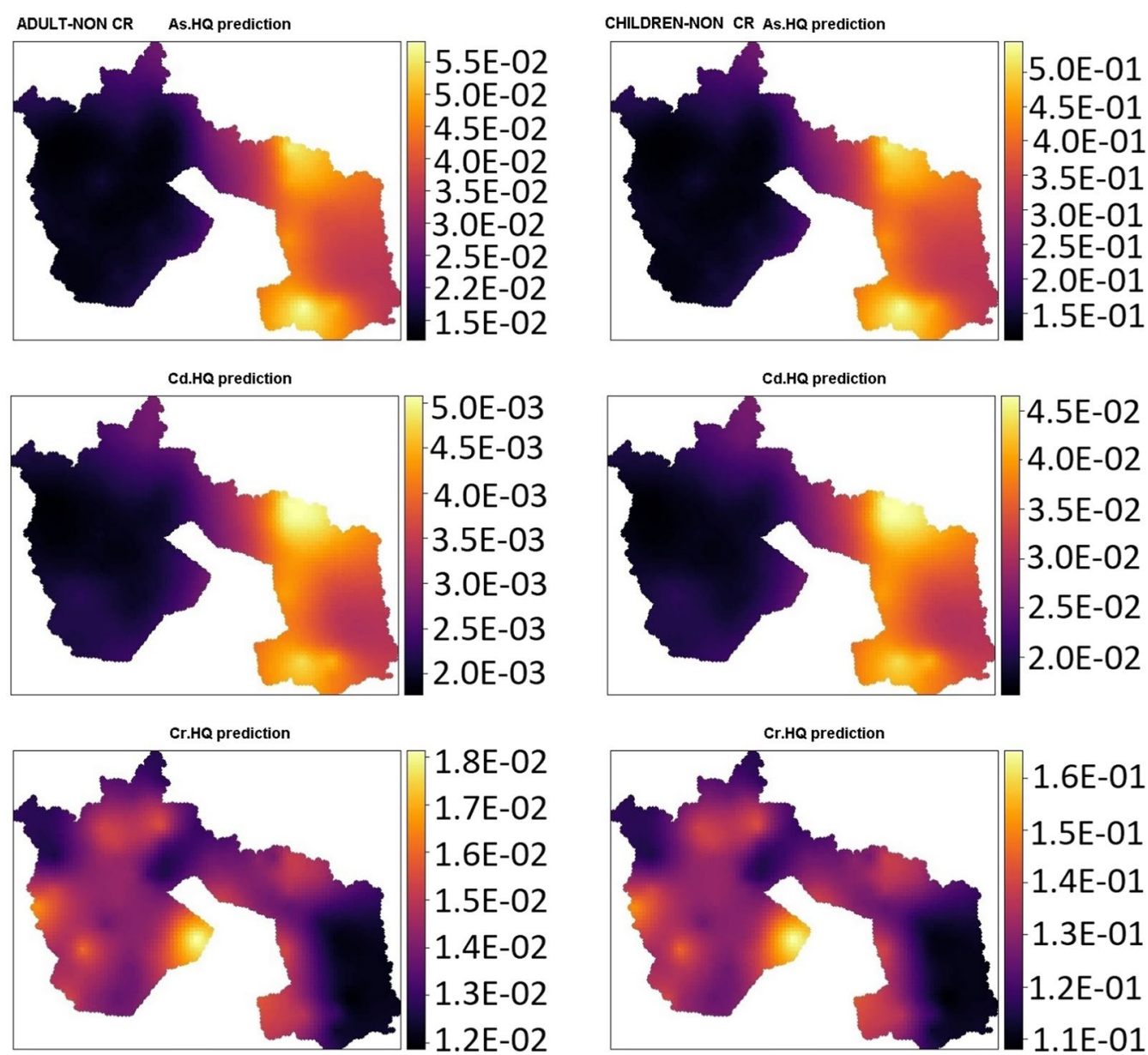

Fig. 9 Spatial distribution of hazard quotient (HQ) of PTEs (As, $\mathrm{Cd}$ and $\mathrm{Cr}$ ) per sampled location

exposed, a non-carcinogenic adverse impact on an adult is not likely.

The spatial distribution of the hazard quotient of the PTEs per sample location suggested that the $\mathrm{As}, \mathrm{Pb}$, and Cd hazard quotient (AsHQ, PbHQs and CdHQs) for both children and adults showed similar colour patterns and hotspots in the northeastern and the south-eastern part of the map (see Figs. 9 and 11). The steel industry and agricultural activities in the suburbs are extremely probable to account for the hotspots, predicated on the commonality of the hazard quotient maps of $\mathrm{As}, \mathrm{Pb}$, and $\mathrm{Cd}$. Chromium and manganese also share similar colour patterns of the hazard quotient spatial distribution map. Both (CrHQs and MnHQs) showed hotspots at the southwestern part of the map and moderate-to-low patches all over (see Figs. 9 and 10). This might be attributable to the usage of phosphate fertilizer and fungicides on agricultural fields to increase yield. This is supported by the estimated PMF, which revealed that $\mathrm{Cr}$ and $\mathrm{Mn}$ were the major PTEs in the factor 3 loadings.
Copper and nickel share similar hotspots pattern in the northwestern and the northeastern part of the hazard quotient spatial distribution map (see Fig. 10). Nevertheless, Ni showed more clearer or denser hotspots than copper. The PMF factor discharged confirms the hotspot pattern of $\mathrm{Cu}$ and $\mathrm{Ni}$ since $\mathrm{Cu}$ and $\mathrm{Ni}$ were the dominant PTEs in factor 4. Zinc showed a hotspot in the northwestern part of the map, which might be attributed to agriculture fertilizer and other tenants such as steel and metal industries that use zinc to coat iron and steel as a protective layer to inhibit corrosion.

The spatial distribution map of the adult and children hazard indexes has a similar colour pattern and hotspots. The children's degree of prediction based on the precise scale, on the other hand, suggested that the children residing within the enclave of the northeastern and south-eastern parts of the HI children spatial distribution map are exposed and vulnerable to PTEs (see Fig. 11). Therefore, premised on the children's HI distribution map scale, it can be inferred that HI values of 


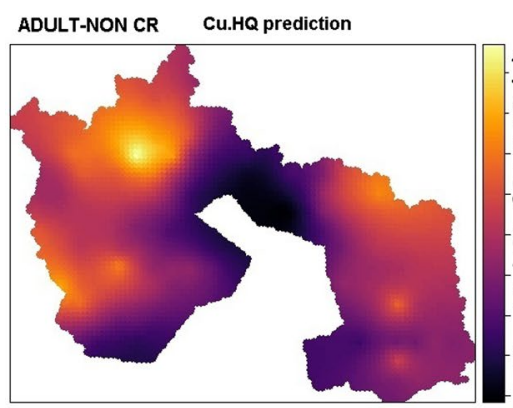

$1.0 \mathrm{E}-03$

$9.5 \mathrm{E}-04$

$9.0 \mathrm{E}-04$

8.5E-04

8.0E-04

7.5E-04

$7.0 \mathrm{E}-04$

$6.5 \mathrm{E}-04$

$6.0 \mathrm{E}-04$
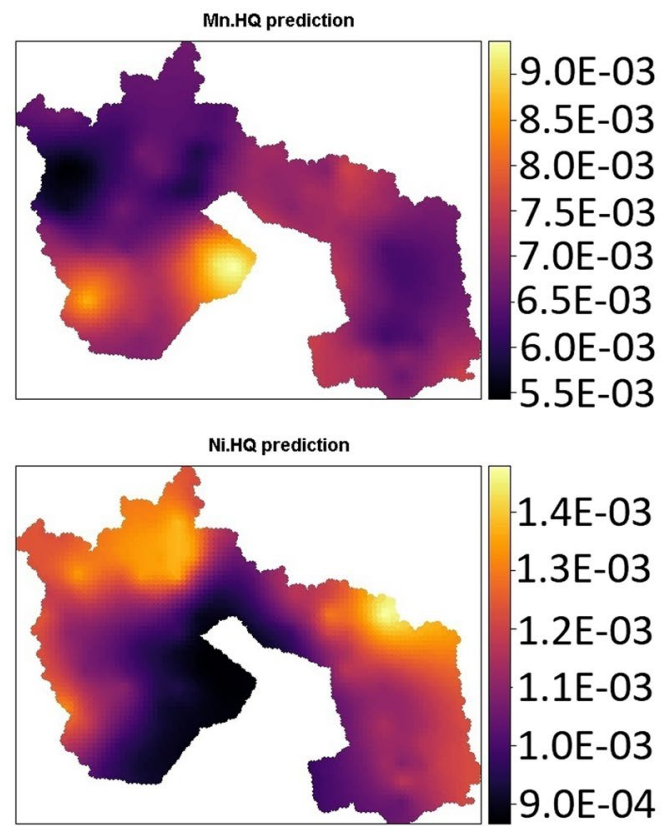

CHILDREN-NON CR CU.HQ prediction

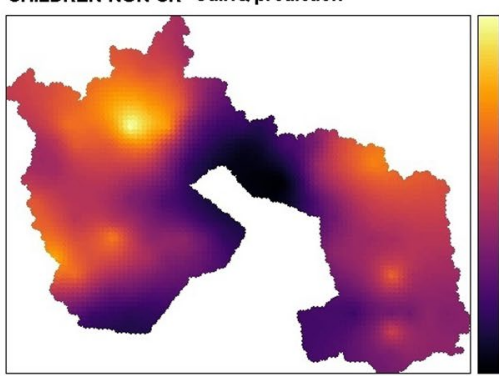

$9.5 \mathrm{E}-03$

$9.0 \mathrm{E}-03$

$8.5 \mathrm{E}-03$

$8.0 \mathrm{E}-03$

7.5E-03

7.0E-03

$6.5 \mathrm{E}-03$

$6.0 \mathrm{E}-03$

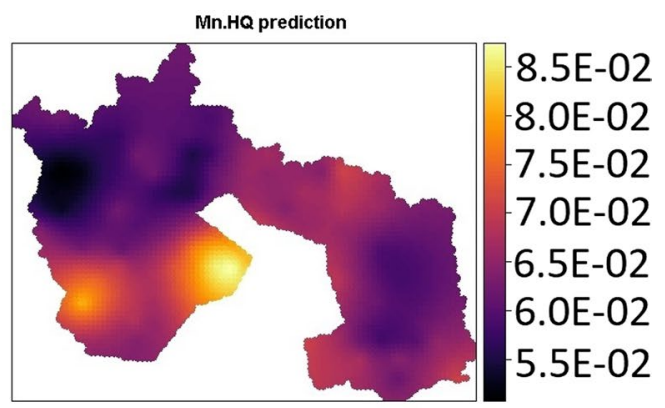

Ni.HQ prediction

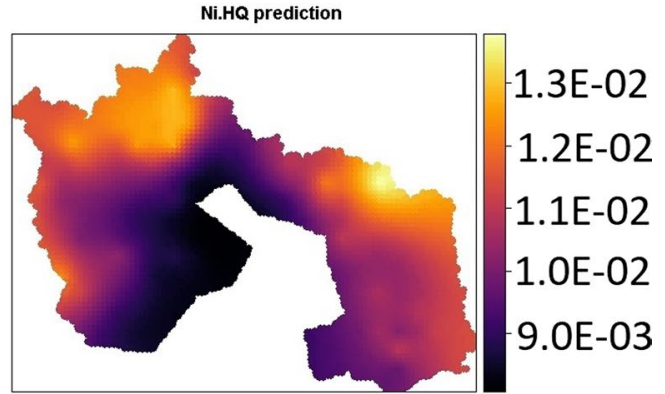

Fig. 10 Spatial distribution of hazard quotient (HQ) of PTEs (Cu, Mn and Ni) per sampled location

0.8 or higher are risk-prone areas, and thus corrective action should be made to mitigate the imminent threats to children.

\section{Carcinogenic risk}

$\mathrm{CDI}_{\text {total }}$, TCR, and $\mathrm{CR}$ for both children and adults were computed, as shown in Additional file 1: Tables S11$\mathrm{S} 14$. The chronic daily intake was calculated for $\mathrm{Cd}, \mathrm{Cr}$, $\mathrm{Pb}, \mathrm{Ni}$, and As. The $\mathrm{CDI}_{\text {total }}$ for adults and children are given in this descending order $\mathrm{Pb}>\mathrm{Cr}>\mathrm{Ni}>\mathrm{As}>\mathrm{Cd}$. The $\mathrm{CDI}_{\text {total }}$ for children per sampled location for each PTE ranges between $1.20 \mathrm{E}-05$ to $6.89 \mathrm{E}-05(\mathrm{Cr})$, $5.33 \mathrm{E}-06$ to $4.65 \mathrm{E}-05(\mathrm{Ni}), 2.03 \mathrm{E}-06$ to $3.34 \mathrm{E}-05$ (As) $1.05 \mathrm{E}-05$ to $1.71 \mathrm{E}-04(\mathrm{~Pb})$ and $6.65 \mathrm{E}-07$ to $7.99 \mathrm{E}-06(\mathrm{Cd})$, whereas the adults $\mathrm{Cr} 5.13 \mathrm{E}-06$ to $2.95 \mathrm{E}-05$, Ni $2.29 \mathrm{E}-06$ to $1.99 \mathrm{E}-05$, As $8.71 \mathrm{E}-07$ to $1.43 \mathrm{E}-05, \mathrm{~Pb} 4.50 \mathrm{E}-06$ to $7.32 \mathrm{E}-05$ and $\mathrm{Cd} 2.85 \mathrm{E}-07$ to $3.42 \mathrm{E}-06$. Regardless of the estimated value of the PTEs, children's CDI totals were higher than adults. PTEs cause various health issues in children, including cardiovascular disease, poor respiratory function, cognitive deficits, reproductive toxicity, and bone damage [104]. Adults and children had higher $\mathrm{Cr} \mathrm{CDI}_{\text {totals }}$ than the other PTEs. Furthermore, children's $\mathrm{CDI}_{\text {total }}$ was significantly higher than adults' (see Additional file 1: Tables S11 and S12). The CR for all PTEs in adults was found to be significantly lower than that of children.

The difference in measured values per sampled location exhibited different values for TCR. Based on the maximum and minimum values of the estimated TCR, it was apparent that the TCR of the children at all the observation points were found to be higher than that of the adult. The results revealed that $13.05 \%$ (i.e. $1 \times 10$ ${ }^{-4}$ to $2.60 \mathrm{E}^{-04} 13.04 \%$, that is 15 sampled points out of $115)$ of the sampled locations estimated TCR values for children were above $1 \times 10^{-6}$ to $1 \times 10^{-4}$. However, the TCR estimated (for children) indicated that $45.22 \%$ (i.e. $7.02 \mathrm{E}-05$ to $9.59 \mathrm{E}-05$, that is 52 sampled points 
ADULT-NON CR $\quad \mathrm{Pb}$. HQ prediction

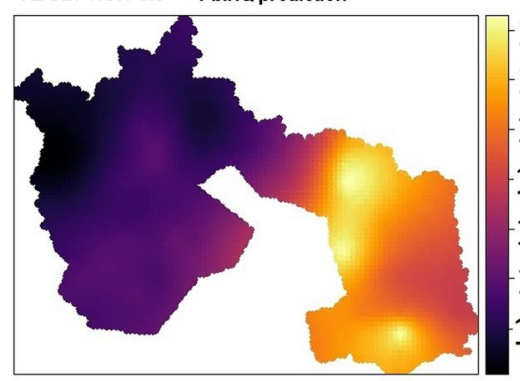

Zn.HQ prediction

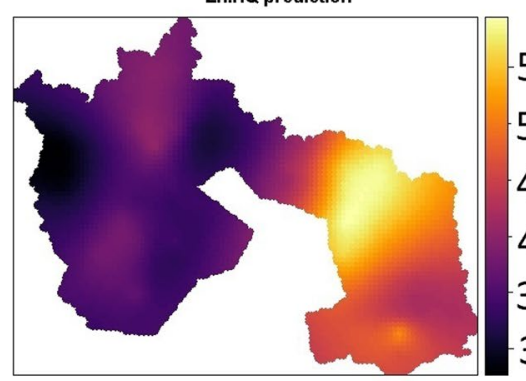

-5.5E-04

$5.0 \mathrm{E}-04$

4.5E-04

4.0E-04

$3.5 \mathrm{E}-04$

3.0E-04

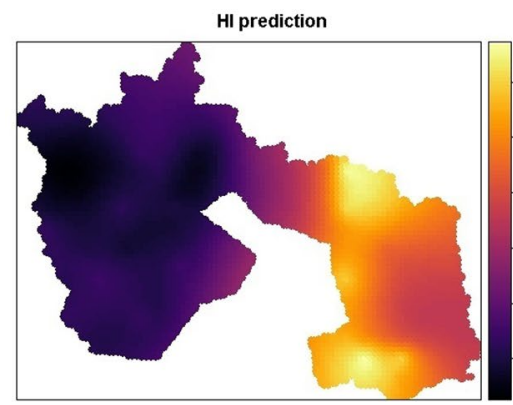

$1.2 \mathrm{E}-02$

$1.0 \mathrm{E}-02$
$2.2 \mathrm{E}-02$

$2.0 \mathrm{E}-02$

$1.8 \mathrm{E}-02$

$1.6 \mathrm{E}-02$

$1.4 \mathrm{E}-02$

CHILDREN-NON CR Pb.HQ prediction

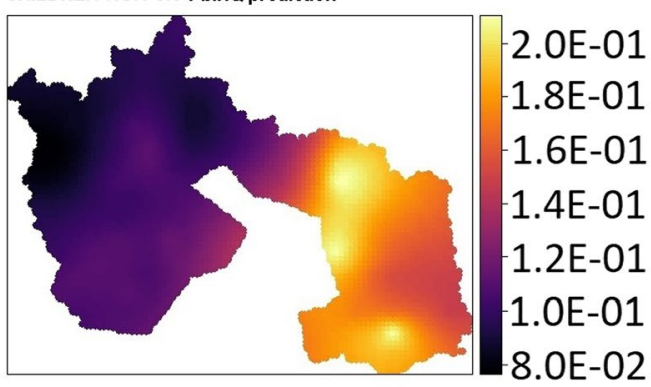

Zn.HQ prediction

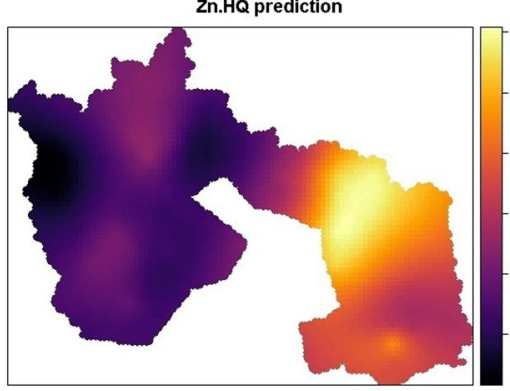

$5.5 \mathrm{E}-03$

$5.0 \mathrm{E}-03$

$4.5 \mathrm{E}-03$

$4.0 \mathrm{E}-03$

$3.5 \mathrm{E}-03$

3.0E-03

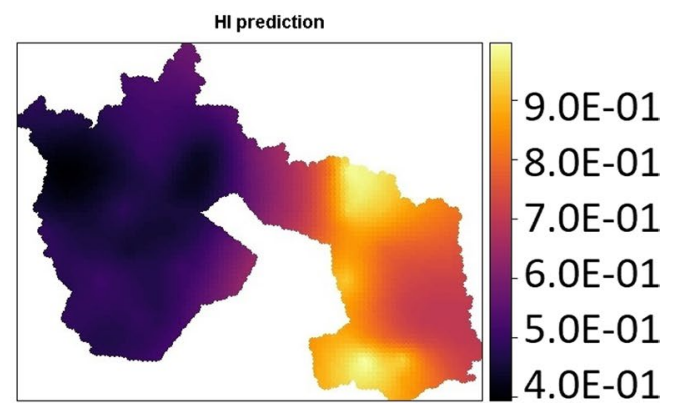

Fig. 11 Spatial distribution of hazard quotient $(\mathrm{HQ})$ of PTEs ( $\mathrm{Pb}$ and $\mathrm{Zn}$ ) and health index $(\mathrm{HI})$ per sampled location

out of 115) of the sampled locations are on the verge of exceeding the carcinogenic risk threshold if corrective measures are not enforced (see Additional file 1: Table S11 and S12). Nevertheless, several sampled locations' estimated TCR for adults exceeded the permissible threshold, while $2.16 \%$ (i.e. $7.26 \mathrm{E}-05$ to $8.78 \mathrm{E}-05$, or 3 out of 115 sampled locations) are on the cusp of exceeding the threshold. Due to the variability of measured PTEs values per sample location, the tendency of carcinogenic risk to befall a child is higher than that of an adult. Based on location-wise sampled data, the carcinogenic risk of the study area implies that some of the sample locations are carcinogenically risky to children compared to adults.

As a result, the likelihood of indigenous peoples, particularly children, being exposed to carcinogenic-related health risks is significant at some sample locations (13.04\% or 15 sampling points out of 115) for children. Furthermore, the CR and HI of children were shown to be higher than that of adults, showing that children are nevertheless more likely to be exposed to PTEs because of their behavioural patterns, which increase the propensity for skin, particularly hand contact.

The spatial prediction of As and Cd carcinogenic risk for adults and children showed a similar hotspot pattern in the northeastern and south-eastern parts of the map (see Fig. 12). However, the hotspots anticipated that children with carcinogenic arsenic risk (CRAs) had a denser colour pattern, as evidenced by the predicted values. The spatial distribution of children's carcinogenic chromium risk (CRCr) revealed patches of hotspots, mainly in the northwestern and southwestern parts of the map (see Fig. 12). On the other hand, the adult displayed sporadic dotted moderate distribution with a broad scale of mild, moderate distribution across the study area. Nickel carcinogenic risk prediction, on the other hand, revealed moderate hotspots with a combination of high patches of hotspots in the northwest and the majority of the 

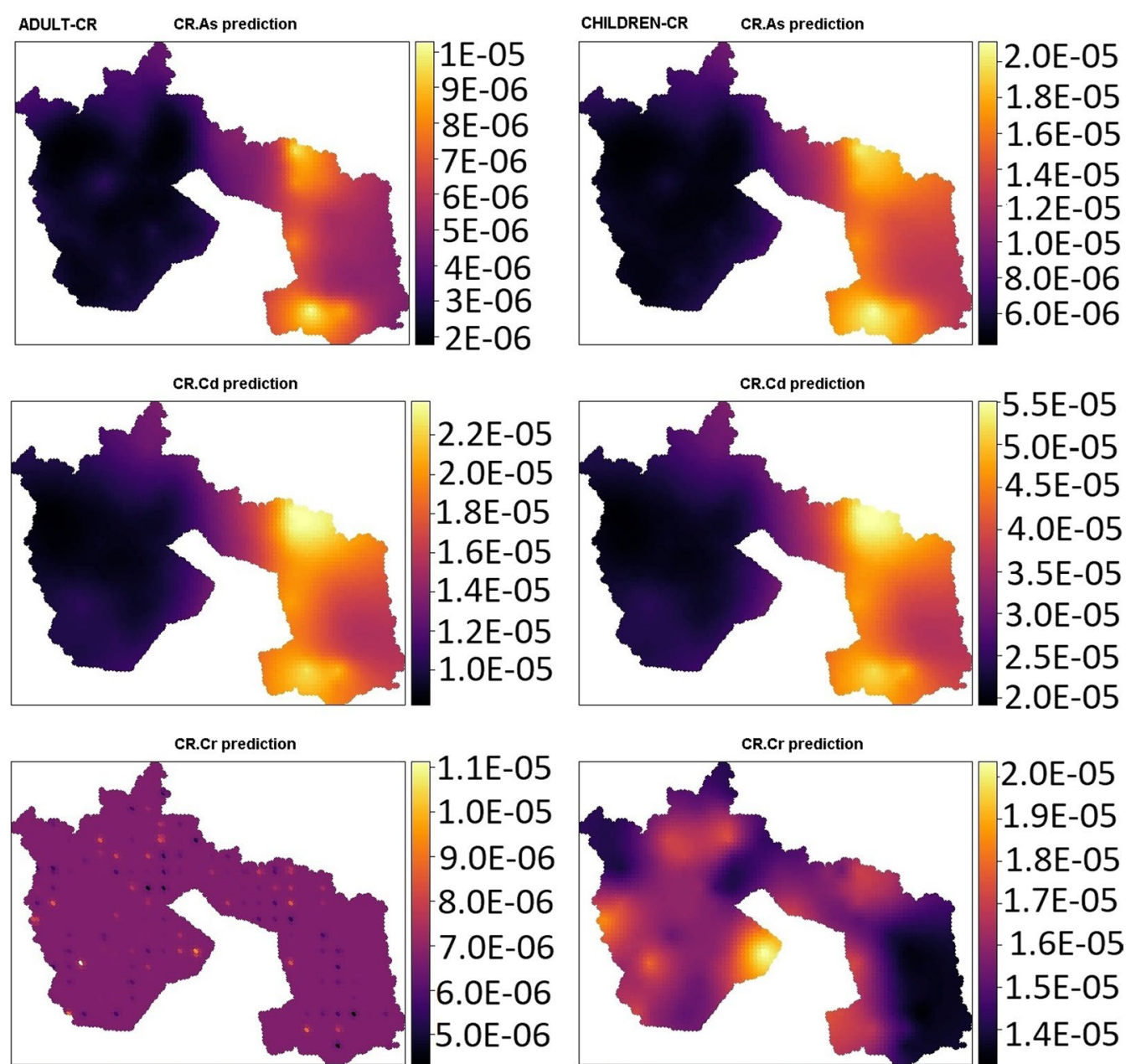

Fig. 12 Spatial distribution of hazard quotient (HQ) of PTEs (As, $\mathrm{Cd}$ and $\mathrm{Cr}$ ) per sampled location

eastern enclave for both adults and children (see Fig. 13). Despite the similarities, the predicted values showed that the degree of exposure to children is greater than that of adults. The carcinogenic exposure rate of children to that of adults for $\mathrm{Pb}(\mathrm{CRPb})$ distribution map revealed moderate to high hotspots for children from the northeast to the southwest. Meanwhile, the adult $\mathrm{CRPb}$ map prediction revealed a continuous low hotspot with multiple dotted hotspots from the northeastern to the southwestern part of the map (see Fig. 13). When the current TCR is compared to similar studies conducted by Weissman nova et al. [105] in Ostrava, Czech Republic, it appears that $\mathrm{Pb}$ poses a significant health carcinogenic risk, $\mathrm{Cd}$ poses a moderate risk, and $\mathrm{Cr}$ poses a very high risk to children. This confirms the current study's findings that children are more vulnerable to PTE-related health risks than adults. In contrast, Kebonye et al. [106] affirmed the recent findings that children are more susceptible to PTEs exposure than adults in riverine soils, Příbram (Czech Republic).

The TCR maps for the children and adults have similar hotspot patterns from the northeast to the southwest (see Fig. 13). The TCR of that of children predicted values, on the other hand, revealed that the children residing within the enclave of the northeastern to the southern were in imminent danger. It can be inferred from the moderate to high hotspots patterns that begin at 1.0E-04 and higher (children TCR map) suggest that the risk associated with carcinogenic-related health issues in children, such as cancer of the skin, kidney, bladder, lung, prostate, and stomach, may occur earlier or later in their life journey. Numerous studies show that PTEs amass in fat tissues and subsequently negatively impact functions of the central nervous structure, immune and the endocrine systems, the urogenital and cardiovascular systems, and normal cellular metabolism [107, 108]. 

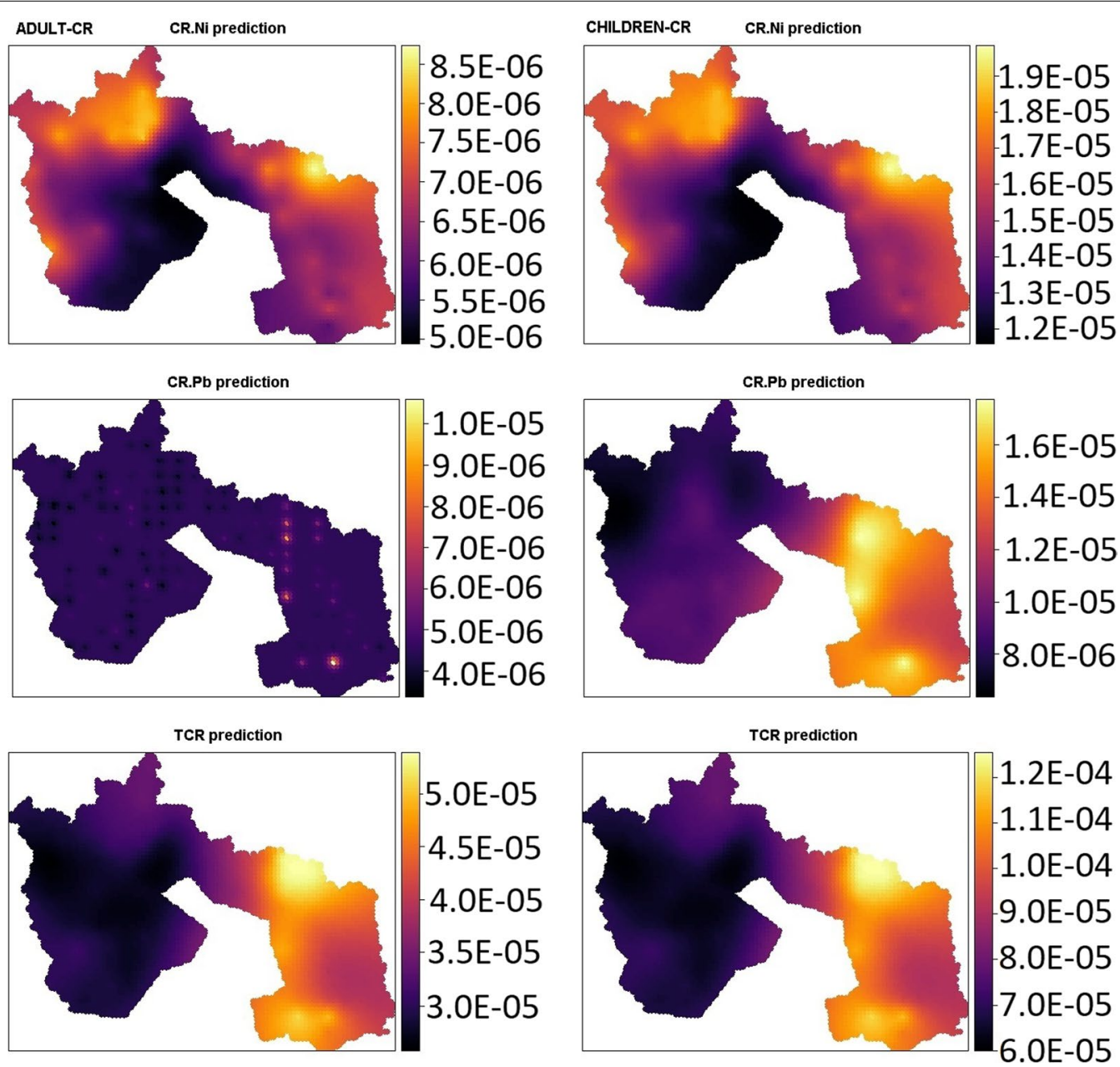

Fig. 13 Spatial distribution of hazard quotient $(\mathrm{HQ})$ of PTEs (Ni and Pb) and total carcinogenic risk (TCR) per sampled location

\section{Conclusion}

In this study, a sample location technique was used to assess human health risk exposure and ecological risk of PTEs pollution in agricultural soils in the district of Frydek Mistek, Czech Republic. The utilization of the local background value and the European average value in the computation of pollution levels such as the single pollution index, pollution load index, and potential ecological risk revealed a variety of pollution levels based on dissimilarities in the threshold limits from disparate geochemical background levels. The PCA identified the primary pollution sources in the research area and confirmed the significant statistics of $71.21 \%$. It suggested that the pollution source originated from a combination of sources, such as anthropogenic and geogenic sources. $\mathrm{Pb}$ and $\mathrm{Zn}$ (factor 1), $\mathrm{Cu}$ and $\mathrm{Ni}$ (factor 2), As (factor 3), and $\mathrm{Mn}$ and $\mathrm{Cr}$ (factor 4) predominate in various factor loadings, according to the source apportionment. The pollution assessment revealed that the pollution levels and ecological risk assessment ranged from low to high for pollution degrees and an exhibition of low to high pollution levels for pollution load index estimation. The health assessment risk for both carcinogenic and noncarcinogenic for adults and children indicated that the children are more exposed to adults. The sampled pointwise health risk assessment suggested that $13.05 \%$ of the totals sample locations are carcinogenically risky to children, and 6.04 of the sampled locations are likewise noncarcinogenically risky. The health risk spatial distribution map exposed the ecologically risky areas imminent to human health, especially children. PTEs in the soil can be increased by continually utilizing agricultural inputs and other anthropogenic activities such as the steel production industries. Due to the variability in observed PTEs concentration, the traditional approach of estimating health risk using mean concentration does not accurately 
reflect the health condition of the area under study. We suggest that using the sampled location approach for future health risk assessment computations is essential. This enables the researcher to fully comprehend the study area and proffer remedial countermeasures at ecologically risky locations and on the verge of entering the high-risk zone. In general, the findings of this study are both informative and practical knowledge of the contamination of PTEs within the district of Frydek Mistek and the health-related risk status of individuals living in the neighbourhood.

\section{Supplementary Information}

The online version contains supplementary material available at https://doi. org/10.1186/s12302-021-00577-w.

\begin{abstract}
Additional file 1: Table S1. Exposure factors used in CDI estimation for non-carcinogenic and carcinogenic risk. Table S2. Shows the calculated single pollution index (PI) for the EAV, and the results suggested that the pollution level of the PTEs ranged from low to high. Table S3. Indicates the esctimated ecological risk index of the study area (geochemical background value used was European average value). Table S4. Indicates the esctimated risk index and pollution load index of the study area (local background value used was European average value). Table S5. Indicates the estimated single pollution index of the study area (geochemical background value used was local background value). Table S6. Indicates the estimated ecological risk of the study area (geochemical background value used was local background value) (geochemical background value used was local background value). Table S7. Children chronic daily intake total for PTEs (non carcinogenic). Table S8. Adult chronic daily intake total for PTEs (non carcinogenic). Table S9. Children Hazard quotient and health index. Table S10. Adult Hazard quotient and health index. Table S11. Children carcinogenic risk and total carcinogenic risk. Table S12. Adult carcinogenic risk and total carcinogenic risk. Table S13 Children chronic dailiy intake (carcinogenic risk). Table S14. Adult chronic daily intake (carcinogenic risk). Table S15. Raw data used for the study.
\end{abstract}

\section{Acknowledgements}

The Czech University of Life Sciences Prague funded this research with an internal Ph.D. grant number. SV20-5-21130 from the Faculty of Agrobiology, Food, and Natural Resources (CZU). The Czech Ministry of Education, Youth, and Sports (Project No. CZ.02.1.01/0.0/0.0/16 019/0000845) also aided. Finally, there is the Centre of Excellence (Centre of the investigation of synthesis and transformation of nutritional substances in the food chain in interaction with potentially risk substances of anthropogenic origin: comprehensive assessment of the soil contamination risks for the quality of agricultural products, NutRisk Centre).

\section{Authors' contributions}

PCA: conceptualization, methodology, investigation, writing —original draft, writing — review and editing. JK: investigation, writing review and editing. NMK: investigation, writing review and editing. LB: investigation, supervision, review and editing. RV: data collection and proofreading. OD: data investigation and analysis. KM: data analysis. All authors read and approved the final manuscript.

\section{Funding}

Czech University of Life Sciences Prague (CZU) Agrobiology, Food and Natural Resources.

\section{Availability of data and materials}

The data are available upon request.

\section{Declarations}

Ethics approval and consent to participate

Not applicable.

\section{Consent for publication}

Not applicable.

\section{Animal research}

Not applicable.

\section{Competing interests}

The authors declare that they have no known competing personal interests or relationships that could have appeared to influence the scientific work in this manuscript.

Received: 13 August 2021 Accepted: 27 November 2021

Published online: 13 December 2021

References

1. FAO (2015) Status of the World's Soil Resources. Intergov Tech Panel Soils $123-126$

2. Mamut A, Eziz M, Mohammad A, Anayit M (2017) Human and ecological risk assessment: An International Journal The spatial distribution, contamination, and ecological risk assessment of heavy metals of farmland soils in Karashahar-Baghrash Oasis, northwest China. Int J 23:1300-1314. https://doi.org/10.1080/10807039.2017.1305263

3. Khelfaoui M, Medjram MS, Kabir A et al (2020) Chemical and mineralogical characterization of weathering products in mine wastes, soil, and sediment from the abandoned $\mathrm{Pb} / \mathrm{Zn}$ mine in Skikda, Algeria. Environ Earth Sci 79:293. https://doi.org/10.1007/s12665-020-09043-x

4. Massas I, Gasparatos D, loannou D, Kalivas D (2018) Signs for secondary buildup of heavy metals in soils at the periphery of Athens International Airport, Greece. Environ Sci Pollut Res 25(1):658-671

5. Zhang J, Li H, Zhou Y et al (2018) Bioavailability and soil-to-crop transfer of heavy metals in farmland soils: a case study in the Pearl River Delta, South China. Environ Pollut 235:710-719. https://doi.org/10.1016/j. envpol.2017.12.106

6. Dong B, Zhang R, Gan Y et al (2019) Multiple methods for the identification of heavy metal sources in cropland soils from a resource-based region. Sci Total Environ 651:3127-3138. https://doi.org/10.1016/j.scito tenv.2018.10.130

7. Wang S, Cai LM, Wen HH et al (2019) Spatial distribution and source apportionment of heavy metals in soil from a typical county-level city of Guangdong Province, China. Sci Total Environ 655:92-101. https:// doi.org/10.1016/j.scitotenv.2018.11.244

8. Agyeman PC, Ahado SK, Kingsley J et al (2021) Source apportionment, contamination levels, and spatial prediction of potentially toxic elements in selected soils of the Czech Republic. Environ Geochem Health 43:601-620. https://doi.org/10.1007/s10653-020-00743-8

9. Douay F, Roussel H, Pruvot C, Waterlot C (2008) Impact of a smelter closedown on metal contents of wheat cultivated in the neighbourhood. Environ Sci Pollut Res 15:162-169. https://doi.org/10.1065/espr2 006.12 .366

10. Thomas LDK, Hodgson S, Nieuwenhuijsen M, Jarup L (2009) Early kidney damage in a population exposed to cadmium and other heavy metals. Environ Health Perspect 117:181-184. https://doi.org/10.1289/ ehp.11641

11. Bilias F, Nikoli T, Kalderis D, Gasparatos D (2021) Towards a soil remediation strategy using biochar: effects on soil chemical properties and bioavailability of potentially toxic elements. Toxics 9(8):184

12. Bai J, Xiao R, Gong A et al (2011) Assessment of heavy metal contamination of surface soils from typical paddy terrace wetlands on the Yunnan Plateau of China. Phys Chem Earth 36:447-450. https://doi.org/10. 1016/j.pce.2010.03.025

13. Zukowska J, Biziuk M (2008) Methodological evaluation of method for dietary heavy metal intake. J Food Sci 73:R21-R29 
14. Bempah CK, Ewusi A (2016) Heavy metals contamination and human health risk assessment around Obuasi gold mine in Ghana. Environ Monit Assess 188. https://doi.org/10.1007/s10661-016-5241-3

15. Chen H, Teng Y, Lu S et al (2015) Contamination features and health risk of soil heavy metals in China. Sci Total Environ 512-513:143-153. https://doi.org/10.1016/j.scitotenv.2015.01.025

16. Keshavarzi A, Kumar V (2019) Ecological risk assessment and source apportionment of heavy metal contamination in agricultural soils of Northeastern Iran. Int J Environ 29:544-560

17. Dayani M, Mohammadi J (2010) Geostatistical assessment of Pb, Zn and Cd contamination in near-surface soils of the urban-mining transitional region of Isfahan, Iran. Pedosphere 20:568-577. https://doi.org/10.1016/ S1002-0160(10)60046-X

18. Kim RY, Yoon JK, Kim TS et al (2015) Bioavailability of heavy metals in soils: definitions and practical implementation-a critical review. Environ Geochem Health 37:1041-1061. https://doi.org/10.1007/ s10653-015-9695-y

19. Yang Q, Li Z, Lu X et al (2018) A review of soil heavy metal pollution from industrial and agricultural regions in China: pollution and risk assessment. Sci Total Environ 642:690-700. https://doi.org/10.1016/j. scitotenv.2018.06.068

20. Ma W, Tai L, Qiao Z et al (2018) Contamination source apportionment and health risk assessment of heavy metals in soil around municipal solid waste incinerator: A case study in North China. Sci Total Environ 631-632:348-357. https://doi.org/10.1016/j.scitotenv.2018.03.011

21. Eziz M, Mohammad A, Mamut A, Hini G (2018) A human health risk assessment of heavy metals in agricultural soils of Yanqi Basin, Silk Road Economic Belt, China. Hum Ecol Risk Assess 24:1352-1366. https://doi. org/10.1080/10807039.2017.1412818

22. Xu X, Zhao Y, Zhao X et al (2014) Sources of heavy metal pollution in agricultural soils of a rapidly industrializing area in the Yangtze Delta of China. Ecotoxicol Environ Saf 108:161-167. https://doi.org/10.1016/j. ecoenv.2014.07.001

23. Doabi SA, Karami M, Afyuni M, Yeganeh M (2018) Pollution and health risk assessment of heavy metals in agricultural soil, atmospheric dust and major food crops in Kermanshah Province. Iran Ecotoxicol Environ Saf 163:153-164. https://doi.org/10.1016/j.ecoenv.2018.07.057

24. Rinklebe J, Antoniadis V, Shaheen SM et al (2019) Health risk assessment of potentially toxic elements in soils along the Central Elbe River, Germany. Environ Int 126:76-88. https://doi.org/10.1016/j.envint.2019. 02.011

25. Baltas H, Sirin M, Gökbayrak E, Ozcelik AE (2020) A case study on pollution and a human health risk assessment of heavy metals in agricultural soils around Sinop Province, Turkey. Chemosphere 241:125015. https:// doi.org/10.1016/j.chemosphere.2019.125015

26. Kampa M, Castanas E (2008) Human health effects of air pollution. Environ Pollut 151:362-367. https://doi.org/10.1016/j.envpol.2007.06. 012

27. CZso, 2019. Characteristics of the Frýdek-Místek district CZSO in Ostrava [WWW Document]. URL https://www.czso.cz/csu/xt/charakteristika_ okresu frydek mistek. Accessed 10.6.20

28. John K, Agyeman PC, Kebonye NM, Isong IA, Ayito EO, Ofem KI, Qin CZ (2021) Hybridization of cokriging and gaussian process regression modelling techniques in mapping soil sulphur. CATENA 206:105534

29. Weather Spark, 2016. Average Weather in Frýdek-Místek, Czechia, YearRound - Weather Spark [WWW Document]. URL https://weatherspark. com/y/83671/Average-Weather-iFrýdek-Místek-Czechia-Year-Round

30. Kozák J (2010) Soil Atlas of the Czech Republic. 150

31. Vacek $O$, Vašát R, Borůvka L (2020) Quantifying the pedodiversity-elevation relations. Geoderma 373:114441. https://doi.org/10.1016/j.geode rma.2020.114441

32. Huang Y, Chen Q, Deng M et al (2018) Heavy metal pollution and health risk assessment of agricultural soils in a typical peri-urban area in southeast China. J Environ Manage 207:159-168. https://doi.org/10.1016/j. jenvman.2017.10.072

33. Sawut R, Kasim N, Maihemuti B et al (2018) Pollution characteristics and health risk assessment of heavy metals in the vegetable bases of northwest China. Sci Total Environ 642:864-878. https://doi.org/10. 1016/j.scitotenv.2018.06.034

34. Tomlinson DL, Wilson JG, Harris CR, Jeffrey DW (1980) Problems in the assessment of heavy-metal levels in estuaries and the formation of a pollution index. Helgoländer Meeresuntersuchungen 33:566-575. https://doi.org/10.1007/BF02414780

35. Hakanson L (1980) An ecological risk index for aquatic pollution control. A sedimentological approach. Water Res 14:975-1001. https://doi.org/ 10.1016/0043-1354(80)90143-8

36. U.S. EPA (2014) Positive Matrix Factorization (PMF) 5.0-Fundamentals and User Guide

37. Paatero P, Tapper U (1994) Positive matrix factorization: a non-negative factor model with optimal utilization of error estimates of data values. Environmetrics 5:111-126. https://doi.org/10.1002/env.3170050203

38. Paatero $P(1997)$ Least squares formulation of robust non-negative factor analysis. In: Chemometrics and intelligent laboratory systems. Elsevier, pp 23-35

39. Norris G (2008) EPA Positive Matrix Factorization (PMF) 3.0 Fundamentals \& User Guide, US. Environmental Protection Agency. http://www. epa.gov/heasd/products/pmf/pmf.html

40. Wang G, Liu HQ, Gong Y, et al (2017) Risk assessment of metals in urban soils from a typical Industrial city, Suzhou, Eastern China. Int J Environ Res Public Health 14. https://doi.org/10.3390/ijerph14091025

41. US EPA (1989) Risk Assessment Guidance for Superfund. Human Health Evaluation Manual Part A, Interim Final. United States Environ Prot Agency 1 part A:300

42. USEPA (2002) Supplemental Guidance for Developing Soil Screening Levels for Superfund Sites, Appendix D-dispersion Factors Calculations. USA. United States Environ Prot Agency, Washington, DC pp. 4-24

43. Hu X, Zhang Y, Ding Z et al (2012) Bioaccessibility and health risk of arsenic and heavy metals ( $\mathrm{Cd} \mathrm{Co}, \mathrm{Cr}, \mathrm{Cu}, \mathrm{Ni}, \mathrm{Pb}, \mathrm{Zn}$ and $\mathrm{Mn}$ ) in TSP and PM2.5 in Nanjing, China. Atmos Environ 57:146-152. https://doi.org/10. 1016/j.atmosenv.2012.04.056

44. Kohonen T (1982) Self-organized formation of topologically correct feature maps. Biol Cybern 43:59-69. https://doi.org/10.1007/BF00337288

45. Fraser SJ, Dickson BL (2007) A New method for data integration and integrated data interpretation: self-organising maps

46. Li T, Sun G, Yang C et al (2018) Using self-organizing map for coastal water quality classification: towards a better understanding of patterns and processes. Sci Total Environ 628-629:1446-1459. https://doi.org/10. 1016/j.scitotenv.2018.02.163

47. Melssen WJ, Smits JRM, Buydens LMC, Kateman G (1994) Using artificial neural networks for solving chemical problems. Part II. Kohonen selforganising feature maps and Hopfield networks. Chemom Intell Lab Syst. https://doi.org/10.1016/0169-7439(93)E0036-4

48. Kabata-Pendias A (2011) Trace Elements in Soils and Plants. CRC Taylor Fr Group, London New York

49. Tóth G, Hermann T, Da Silva MR, Montanarella L (2016) Heavy metals in agricultural soils of the European Union with implications for food safety. Environ Int 88:299-309

50. Jia Z, Li S, Wang L (2018) Assessment of soil heavy metals for eco-environment and human health in a rapidly urbanization area of the upper Yangtze Basin. Sci Rep 8 https://doi.org/10.1038/s41598-018-21569-6

51. Nemecek J, Podlesakova E (1992) Retrospective experimental monitoring of heavy-metals containing in soils of the Czech Republic. Rostlinna Vyroba 38(6):433-436

52. Chandrasekaran A, Ravisankar R, Harikrishnan N et al (2015) Multivariate statistical analysis of heavy metal concentration in soils of Yelagiri Hills, Tamilnadu, India_spectroscopical approach. Spectrochim Acta Part A Mol Biomol Spectrosc 137:589-600. https://doi.org/10.1016/j.saa.2014. 08.093

53. Karimi Nezhad MT, Tabatabaii SM, Gholami A (2015) Geochemical assessment of steel smelter-impacted urban soils, Ahvaz, Iran. J Geochemical Explor 152:91-109. https://doi.org/10.1016/j.gexplo.2015.02. 005

54. Hou D, He J, Lü C et al (2013) Distribution characteristics and potential ecological risk assessment of heavy metals ( $\mathrm{Cu}, \mathrm{Pb}, \mathrm{Zn}, \mathrm{Cd}$ ) in water and sediments from Lake Dalinouer, China. Ecotoxicol Environ Saf 93:135-144. https://doi.org/10.1016/j.ecoenv.2013.03.012

55. Franco-Uría A, López-Mateo C, Roca E, Fernández-Marcos ML (2009) Source identification of heavy metals in pastureland by multivariate analysis in NW Spain. J Hazard Mater 165:1008-1015. https://doi.org/10. 1016/j.jhazmat.2008.10.118 
56. Nicholson FA, Smith SR, Alloway BJ et al (2003) An inventory of heavy metals inputs to agricultural soils in England and Wales. Sci Total Environ 311:205-219. https://doi.org/10.1016/S0048-9697(03)00139-6

57. Luo L, Ma Y, Zhang S et al (2009) An inventory of trace element inputs to agricultural soils in China. J Environ Manage 90:2524-2530. https:// doi.org/10.1016/j.jenvman.2009.01.011

58. Mantovi P, Bonazzi G, Maestri E, Marmiroli N (2003) Accumulation of copper and zinc from liquid manure in agricultural soils and crop plants

59. Mishima S-I, Inoue T, Kimura R (2004) Estimation of cadmium load on Japanese farmland associated with the application of chemical fertilizers and livestock excreta. Soil Sci Plant Nutr 50:263-267. https://doi.org/ 10.1080/00380768.2004.10408476

60. Rezapour S, Atashpaz B, Moghaddam SS et al (2019) Cadmium accumulation, translocation factor, and health risk potential in a wastewaterirrigated soil-wheat (Triticum aestivum L.) system. Chemosphere 231:579-587. https://doi.org/10.1016/j.chemosphere.2019.05.095

61. Li B, Xiao R, Wang C et al (2017) Spatial distribution of soil cadmium and its influencing factors in peri-urban farmland: a case study in the Jingyang District, Sichuan, China. Environ Monit Assess 189:1-16. https:// doi.org/10.1007/s10661-016-5744-y

62. Li X, Zhang J, Ma J et al (2020) Status of chromium accumulation in agricultural soils across China (1989-2016). Chemosphere 256:127036

63. Yaylali-Abanuz G (2011) Heavy metal contamination of surface soil around Gebze industrial area, Turkey. Microchem J 99:82-92. https:// doi.org/10.1016/.microc.2011.04.004

64. Echevarria G, Massoura ST, Sterckeman T, et al (2006) Assessment and control of the bioavailability of nickel in soils. In: Environmental toxicology and chemistry. pp 643-651

65. Krishna AK, Govil PK (2005) Heavy metal distribution and contamination in soils of Thane-Belapur industrial development area, Mumbai, Western India. Environ Geol 47(8):1054-1061

66. Salonen VP, Korkka-Niemi K (2007) Influence of parent sediments on the concentration of heavy metals in urban and suburban soils in Turku, Finland. Appl Geochem 22:906-918. https://doi.org/10.1016/j.apgeo chem.2007.02.003

67. Goovaerts P (1997) Geostatistics for natural resources and evaluation

68. Al-Mughrabi KI, Vikram A, Poirier R et al (2016) Management of common scab of potato in the field using biopesticides, fungicides, soil additives, or soil fumigants. Biocontrol Sci Technol 26:125-135. https:// doi.org/10.1080/09583157.2015.1079809

69. Rodríguez JA, Nanos N, Grau JM et al (2008) Multiscale analysis of heavy metal contents in Spanish agricultural topsoils. Chemosphere 70:1085-1096. https://doi.org/10.1016/j.chemosphere.2007.07.056

70. Chakraborty S, Weindorf DC, Paul S et al (2015) Diffuse reflectance spectroscopy for monitoring lead in landfill agricultural soils of India. Geoderma Reg 5:77-85. https://doi.org/10.1016/j.geodrs.2015.04.004

71. Khosravi V, Doulati Ardejani F, Yousefi S, Aryafar A (2018) Monitoring soil lead and zinc contents via combination of spectroscopy with extreme learning machine and other data mining methods. Geoderma 318:29-41. https://doi.org/10.1016/j.geoderma.2017.12.025

72. Tepanosyan G, Sahakyan L, Belyaeva O, Saghatelyan A (2016) Origin identification and potential ecological risk assessment of potentially toxic inorganic elements in the topsoil of the city of Yerevan, Armenia. J Geochem Explor 167:1-11. https://doi.org/10.1016/j.gexplo.2016.04.006

73. Li X, Poon CS, Liu PS (2001) Heavy metal contamination of urban soils and street dusts in Hong Kong. Appl Geochem 16:1361-1368. https:// doi.org/10.1016/50883-2927(01)00045-2

74. Arditsoglou A, Samara C (2005) Levels of total suspended particulate matter and major trace elements in Kosovo: a source identification and apportionment study. Chemosphere 59:669-678. https://doi.org/10. 1016/j.chemosphere.2004.10.056

75. Hjortenkrans D, Bergbäck B, Häggerud A (2006) New metal emission patterns in road traffic environments. Environ Monit Assess 117:85-98. https://doi.org/10.1007/s10661-006-7706-2

76. Guan Q, Wang F, Xu C et al (2018) Source apportionment of heavy metals in agricultural soil based on PMF: a case study in Hexi Corridor, Northwest China. Chemosphere 193:189-197. https://doi.org/10.1016/j. chemosphere.2017.10.151

77. Al-Khashman OA, Shawabkeh RA (2009) Metal distribution in urban soil around steel industry beside Queen Alia Airport, Jordan. Environ Geochem Health 31:717-726. https://doi.org/10.1007/s10653-009-9250-9
78. Wang J, Huang Y, Li T et al (2020) Contamination, morphological status and sources of atmospheric dust in different land-using areas of a steelindustry city, China. Atmos Pollut Res 11:283-289. https://doi.org/10. 1016/j.apr.2019.10.014

79. Xiong X, Yanxia L, Wei L et al (2010) Copper content in animal manures and potential risk of soil copper pollution with animal manure use in agriculture. Resour Conserv Recycl 54:985-990. https://doi.org/10. 1016/j.resconrec.2010.02.005

80. Sharif M, Rahman MA ur, Ahmed B, et al (2020) Copper nanoparticles as growth promoter, antioxidant and anti-bacterial agents in poultry nutrition: prospects and future implications. Biol Trace Elem Res 1-12. https://doi.org/10.1007/s12011-020-02485-1

81. Heo JM, Opapeju FO, Pluske JR et al (2013) Gastrointestinal health and function in weaned pigs: a review of feeding strategies to control postweaning diarrhoea without using in-feed antimicrobial compounds. J Anim Physiol Anim Nutr (Berl) 97:207-237. https://doi.org/10.1111/j. 1439-0396.2012.01284.x

82. Cheng Q, Guo Y, Wang W, Hao S (2014) Spatial variation of soil quality and pollution assessment of heavy metals in cultivated soils of Henan Province, China. Chem Speciat Bioavailab 26:184-190. https://doi.org/ 10.3184/095422914X14042081874564

83. Harasim P, FilipekT (2015) Nickel in the environment. J Elem 20:525534. https://doi.org/10.5601/jelem.2014.19.3.651

84. Li XH, Tang ZL, Chu FY, Yang LY (2011) Characteristics of distribution and chemical speciation of heavy metals in environmental mediums around Jinchang mining city, Northwest China. Environ Earth Sci 64:1667-1674. https://doi.org/10.1007/S12665-009-0438-1

85. Chen T, Chang Q, Liu J et al (2016) Identification of soil heavy metal sources and improvement in spatial mapping based on soil spectral information: a case study in northwest China. Sci Total Environ 565:155-164

86. Bhattacharya P, Welch AH, Stollenwerk KG et al (2007) Arsenic in the environment: biology and chemistry. Sci Total Environ 379:109-120. https://doi.org/10.1016/j.scitotenv.2007.02.037

87. Micó C, Recatalá L, Peris M, Sánchez J (2006) Assessing heavy metal sources in agricultural soils of an European Mediterranean area by multivariate analysis. Chemosphere 65:863-872. https://doi.org/10.1016/j. chemosphere.2006.03.016

88. Jayasumana MACS, Paranagama PA, Amarasinghe, et al (2013) Possible link of Chronic arsenic toxicity with Chronic Kidney Disease of unknown etiology in Sri Lanka. J Nat Sci Res www.iiste.org ISSN 3

89. Jayasumana C, Fonseka S, Fernando A et al (2015) Phosphate fertilizer is a main source of arsenic in areas affected with chronic kidney disease of unknown etiology in Sri Lanka. Springerplus 4:1-8. https://doi.org/ 10.1186/s40064-015-0868-Z

90. Liu L, An Y, Ma J et al (2020) Source apportionment of soil heavy metals in Beijing Urban Park based on the UNMIX model. Res Environ Sci 33:2856-2863. https://doi.org/10.13198/j.issn.1001-6929.2020.03.40

91. Zhang X, Zhong T, Liu L et al (2016) Chromium occurrences in arable soil and its influence on food production in China. Environ Earth Sci 75:1-8. https://doi.org/10.1007/s12665-015-5078-z

92. Bradl HB (2005) Chapter 1 Sources and origins of heavy metals. Interface Sci Technol 6:1-27. https://doi.org/10.1016/S1573-4285(05) 80020-1

93. Shaw River (2017) Manganese Fact Sheet. 2

94. Alvarez-Guerra M, González-Piñuela C, Andrés A et al (2008) Assessment of Self-Organizing Map artificial neural networks for the classification of sediment quality. Environ Int 34:782-790. https://doi.org/10.1016/j. envint.2008.01.006

95. Wang Z, Xiao J, Wang L, Liang T, Guo Q, Guan Y, Rinklebe J (2020) Elucidating the differentiation of soil heavy metals under different land uses with geographically weighted regression and self-organizing map. Environ Pollut 260:114065

96. Kowalska JB, Mazurek R, Gąsiorek M, Zaleski T (2018) Pollution indices as useful tools for the comprehensive evaluation of the degree of soil contamination-a review. Environ Geochem Health 40:2395-2420

97. Agyeman PC et al (2021) Multi-geochemical background comparison and the identification of the best normalizer for the estimation of PTE contamination in agricultural soil. Environ Geochem Health. https://doi. org/10.1007/s10653-021-01109-4 
98. Agyeman PC, Ahado SK, John K, et al (2021) Health risk assessment and the application of CF-PMF: a pollution assessment-based receptor model in an urban soil. J Soils Sediments 1-20. https://doi.org/10.1007/ s11368-021-02988-X

99. Han Q, Wang M, Cao J et al (2020) Health risk assessment and bioaccessibilities of heavy metals for children in soil and dust from urban parks and schools of Jiaozuo, China. Ecotoxicol Environ Saf 191:110157. https://doi.org/10.1016/j.ecoenv.2019.110157

100. Natasha SM, Khalid S et al (2020) A critical review of mercury speciation, bioavailability, toxicity and detoxification in soil-plant environment: ecotoxicology and health risk assessment. Sci Total Environ 711:134749. https://doi.org/10.1016/j.scitotenv.2019.134749

101. Wang F, Guan Q, Tian J et al (2020) Contamination characteristics, source apportionment, and health risk assessment of heavy metals in agricultural soil in the Hexi Corridor. CATENA 191:104573. https://doi. org/10.1016/j.catena.2020.104573

102. Bhandari G, Atreya K, Scheepers PTJ, Geissen V (2020) Concentration and distribution of pesticide residues in soil: non-dietary human health risk assessment. Chemosphere 253:126594. https://doi.org/10.1016/j. chemosphere.2020.126594

103. Zheng S, Wang Q, Yuan Y, Sun W (2020) Human health risk assessment of heavy metals in soil and food crops in the Pearl River Delta urban agglomeration of China. Food Chem 316:126213. https://doi.org/10. 1016/j.foodchem.2020.126213

104. Madrigal J, Persky V, Pappalardo A, Argos M (2018) Association of heavy metals with measures of pulmonary function in youth: findings from the 2011-2012 National Health and Nutrition Examination Survey (NHANES). ISEE Conf Abstr 2018. https://doi.org/10.1289/isesisee.2018. 003.03.26

105. Doležalová Weissmannová H, Mihočová S, Chovanec P, Pavlovský J (2019) Potential ecological risk and human health risk assessment of heavy metal pollution in industrial affected soils by coal mining and metallurgy in Ostrava, Czech Republic. Int J Environ Res Public Health 16(22):4495

106. Kebonye NM, Eze PN, John K, Agyeman PC, Němeček K, Borůvka L (2021) An in-depth human health risk assessment of potentially toxic elements in highly polluted riverine soils, Príbram (Czech Republic). Environ Geochem Health 1-17

107. Wang Q, Liu J, Cheng S (2015) Heavy metals in apple orchard soils and fruits and their health risks in Liaodong Peninsula, Northeast China. Environ Monit Assess 187. https://doi.org/10.1007/s10661-014-4178-7

108. Wang WX (2013) Dietary toxicity of metals in aquatic animals: recent studies and perspectives. Chinese Sci Bull 58:203-213. https://doi.org/ 10.1007/s11434-012-5413-7

109. IGME (2012) Geochemical atlas of Spain (Atlas Geoquímico de España). Instituto Geológico y Minero de España, Madrid In Spanish. Bravo S, García-Ordiales E, García-Navarro FJ, Amorós JÁ, Pérez-de-Los-Reyes C, Jiménez-Ballesta R, Higueras P (2019)

110. Erhart E, Hartl W, Putz B (2008) Total soil heavy-metal concentrations and mobile fractions after 10 years of biowaste-compost fertilization. $J$ Plant Nutr Soil Sci 171(3):378-383

111. Tarvainen T, Kallio E (2002) Baselines of certain bioavailable and total heavy metal concentrations in Finland. Appl Geochem 17(8):975-980

112. Liu X, Zhang W, Hu Y et al (2015) Arsenic pollution of agricultural soils by concentrated animal feeding operations (CAFOs). Chemosphere 119:273-281. https://doi.org/10.1016/j.chemosphere.2014.06.067

\section{Publisher's Note}

Springer Nature remains neutral with regard to jurisdictional claims in published maps and institutional affiliations.

\section{Submit your manuscript to a SpringerOpen ${ }^{\circ}$ journal and benefit from:}

- Convenient online submission

- Rigorous peer review

- Open access: articles freely available online

- High visibility within the field

- Retaining the copyright to your article

Submit your next manuscript at $\boldsymbol{\nabla}$ springeropen.com 